\title{
Investigations towards the Synthesis of 5-Amino-L-lyxofurano- sides and 4-Amino-lyxopyranosides and NMR Analysis
}

\author{
Alba Diez-Martinez* (D) \\ Ramanarayanan Krishnamurthy* \\ The Department of Chemistry, The Scripps Research Institute, \\ 10550 North Torrey Pines Road, La Jolla, CA 92037, USA \\ albadmo@gmail.com \\ rkrishna@scripps.edu
}

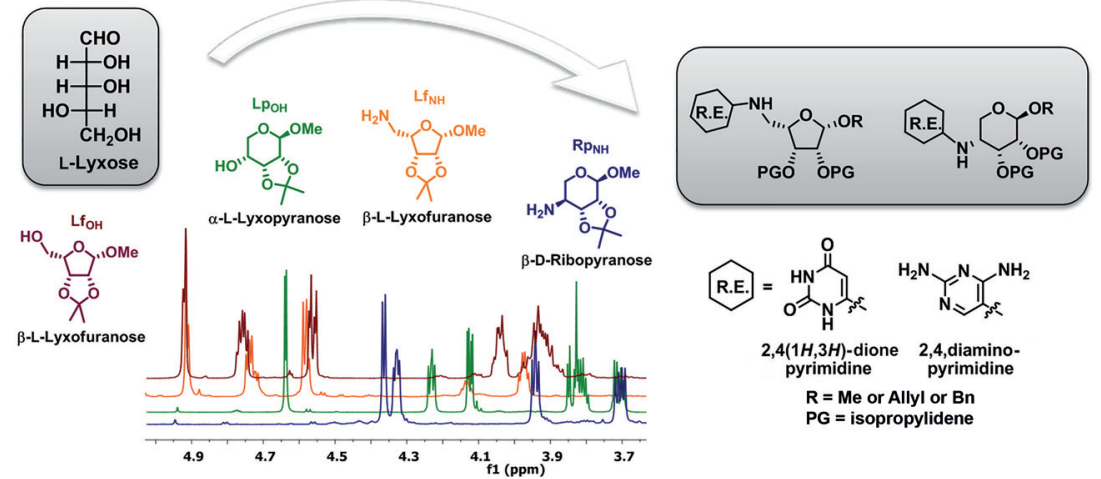

Received: 02.04.2017

Accepted after revision: 12.05.2017

Published online: 01.06 .2017

DOI: 10.1055/s-0036-1588859; Art ID: so-2017-d0014-op

License terms: CCO

Abstract The reactivity of trifluoromethanesulfonyl esters derived from L-lyxofuranosides and L-lyxopyranosides was investigated with various 5 -aminopyrimidines as nucleophiles with the expectation to synthesize $\mathrm{N}$-substituted 5 -amino-ribosugars. The lyxopyranoside forms were found to be unreactive, while the lyxofuranoside forms were found to be reactive with 5 -aminopyrimidines, yielding novel $\mathrm{N}$-substituted 5-amino-lyxofuranosides. We report on the synthesis of these novel $\mathrm{N}$-substituted lyxofuranosides and the systematic analyses of NMR data that demonstrate trends within each series: furano-, pyrano-, $\beta$ - and $\alpha$ - anomers of L-lyxose and $\beta$-D-ribopyranoside forms. The data call for caution when identifying these monosaccharides in isomeric mixtures.

Key words L-lyxofuranoses, L-lyxopyranoses, D-ribopyranoses, conformation analysis, heterocycles, NMR spectroscopy

In our research exploring the self-assembly properties of alternative recognition elements such as 5-aminouracil and 2,4,5-triaminopyrimidine substituted-pyrrolidines, it was necessary to develop new $\mathrm{N}$-substituted 4 -amino-D-ribofuranose sugars. ${ }^{1-3}$ We proposed the corresponding Llyxopyranose derivatives as outlined in Scheme 1 as intermediates en route to the final pyrrolidine compounds. This synthetic approach is based on the fact that nucleophiles can attack the $C(4)$ position of a substituted lyxopyranose sugar (with a good leaving group at the $\mathrm{C}(4)$-position) through a bimolecular nucleophilic substitution $\left(\mathrm{S}_{\mathrm{N}} 2\right)$ displacement, resulting in the corresponding ribopyranose framework. ${ }^{4-7}$ However, the synthesis of $\mathrm{N}$-substituted 4amino-D-ribopyranose derivatives proved problematic with amino pyrimidine heterocycles, presumably due to the poor nucleophilicity of these alternative amino nucleobases.

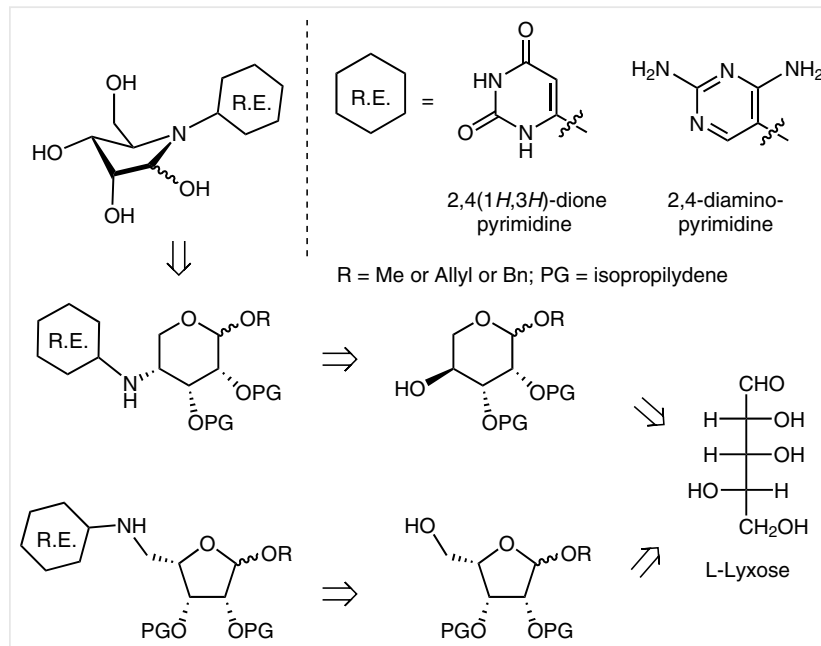

Scheme 1 Proposed retrosynthetic route for the D-azaribofuranose and L-lyxofuranoside-attached heterocycles (R. E. = recognition elements) starting from L-lyxose

For comparison, we also studied the $\mathrm{S}_{\mathrm{N}} 2$ reaction with the L-lyxofuranosyl series with the awareness that 5-amino-heterocycles may react more readily at a primary carbon. When comparing the results of the L-lyxopyranose and L-lyxofuranose series, we found that there could be some uncertainty in the assignments as $\alpha / \beta$ anomeric mixtures of alcohols derived from L-lyxose when they are actually furanoside/pyranoside mixtures. ${ }^{8}$ To clarify this issue, we have synthesized, measured NMR spectra and contrasted the chemical shift trends of the furanosyl and pyranosyl Llyxose series - both from this work and those in the literature - and came to the conclusion that identifying the minor compound in isomeric mixtures of monosaccharides can be crucial and should always rely on accurate identification based on corroborating NMR techniques. 
The starting lyxofuranosides 1-3 were obtained in a one-pot reaction, in which protection of the anomeric position and formation of the acetal were accomplished by heating the starting L-lyxose in the presence of acetone and the appropriate alcohol in acidic medium for short periods of time. Characterization of small amounts of impurities that co-eluted with the desired products showed discrepancies with the results described earlier. ${ }^{8}$ Instead of mixtures of anomers, we identified trace amounts of pyranose products 5-7. In our hands, we could not find mixtures of anomers in any of the cases. The synthesis of starting materials in the L-lyxopyranose series was accomplished by following existing procedures (Scheme 2). ${ }^{5-7,9-12}$ L-Lyxopyranosides 5-7 were prepared in a stepwise fashion. First, protection of the anomeric position by a regular Fischer glycosidation was conducted with corresponding anhydrous alcohol in the presence of an acid. The reaction produced, what we originally thought to be, anomeric mixtures of $\mathbf{4 a - c}$. The ketal protection of these mixtures led to the pyranosyl compounds 5-7 (Scheme 2) and small amounts of the corresponding isomers. We had assumed $\mathbf{5}$ could be mixed with its anomer to a small amount and this was not considered problematic because both anomers would lead to the desired pyrrolidine scaffolds as formulated in Scheme 1. In fact, it turned out to be a mixture of furanose and pyranose forms, which was difficult to purify. Detailed analysis by NMR (see Figure S.54 in the Supporting Information) showed that alcohols $\mathbf{5}$ and $\mathbf{6}$ indeed contained small amounts of furanose forms ( $\mathbf{1}$ and $\mathbf{2}$, respectively), instead of mixtures of (misassigned) anomers. ${ }^{8}$ It is noticeable that the chemical shifts of both isomer protons (5 and 1) are quite different; for example, $0.5 \mathrm{ppm}$ in $\mathrm{CDCl}_{3}$ between both isomers for the anomeric protons (see Table 2), which may have suggested they actually were more different than simply anomers. NOESY NMR spectroscopic analysis of the pure starting materials (1-3 and 5-7) showed that the major anomer is $\beta$ for L-lyxofuranosyl and $\alpha$ for L-lyxopyranosyl alcohols (see also Supporting Information).

To access the sugars tagged with different alternative recognition elements, the corresponding 5-position of the furanosides and 4-position of the pyranosides were modified with good leaving groups that facilitated the attack of different nucleophiles through $\mathrm{S}_{\mathrm{N}} 2$ mechanism. In the case of the $\alpha$-L-lyxopyranose series, inversion of configuration at $C(4)$ generates the $\beta$-D-ribopyranose sugar. Four different nucleophiles were selected for this study (Figure 1). Sodium azide $\mathbf{8}$ was chosen based on the fact that it would lead to a precursor of the corresponding amino compound., ${ }^{43}$ This approach could allow for a later introduction of heterocycles via nucleophilic aromatic substitution. Along with the heterocycles 5-aminouracil $\mathbf{1 0}$ and 2,4,5-triaminopyridine 11, benzyl amine 9 was also utilized for comparison.

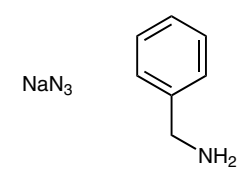

8<smiles>Nc1c[nH]c(=O)[nH]c1=O</smiles>

10<smiles>Nc1ncc(N)c(N)n1</smiles>

11
Figure 1 Nucleophiles utilized for the $S_{N} 2$ reactions with L-lyxose derivatives

The trifluoromethane sulfonate esters of alcohols (at (C) 4 position for the pyranose and (C)5 position for the furanose series) were generated with trifluoromethanesulfonic anhydride in the presence of DMAP and pyridine at $-20{ }^{\circ} \mathrm{C} .{ }^{6,7}$ Reactions were quenched by aqueous work-up upon consumption of starting material. The subsequent $\mathrm{S}_{\mathrm{N}} 2$ reaction was conducted on the crude triflate intermediates

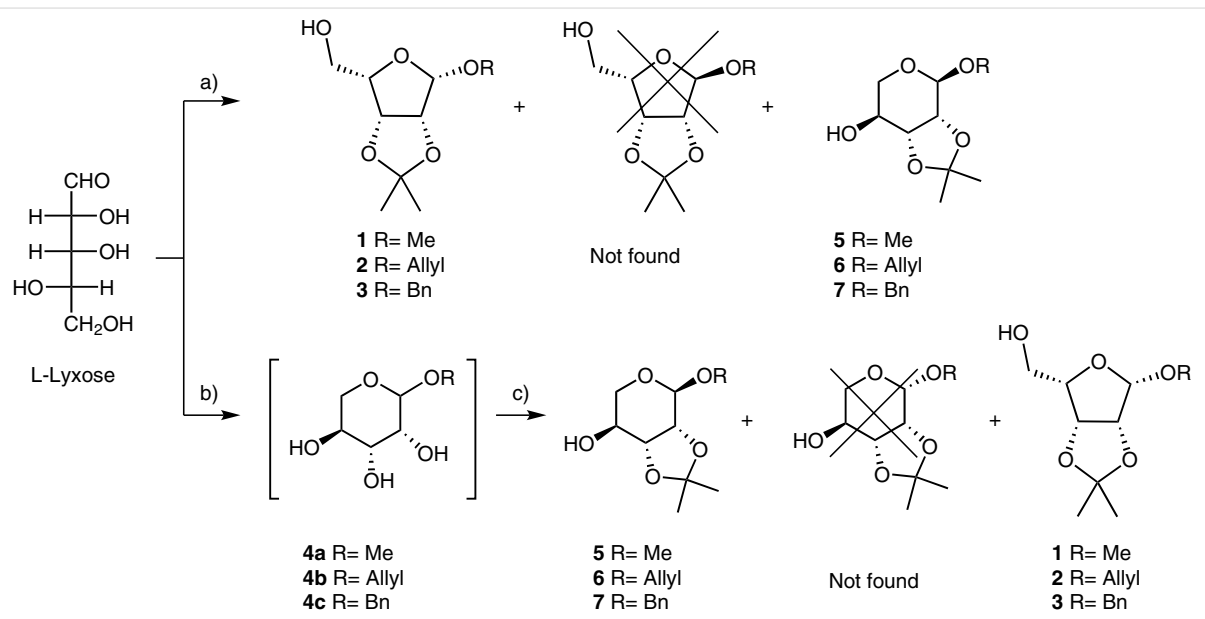

Scheme 2 Synthesis of the ketal-protected $\beta$-furanosides and $\alpha$-pyranosides of L-lyxose. Reagents and conditions: (a) Acetone, $\mathrm{ROH}, \mathrm{H}_{2} \mathrm{SO}_{4}, 60{ }^{\circ} \mathrm{C}, 4 \mathrm{~h}$ (1: 72\% and 5: $<5 \%$; 2: 48\% and 6: $<5 \%$; 3: 37\% and 7: $<5 \%$ ); (b) ROH, reflux, $\mathrm{H}^{+}, 3 \mathrm{~h}$; (c) $\mathrm{HCl}$, acetone, DMP, r.t., $16 \mathrm{~h}$ (yields after two steps: 5: $36 \%$ and 1: $<20 \%$; 6 : $41 \%$ and $2:<10 \% ; 7: 30 \%$ and $3:<5 \%)$. 


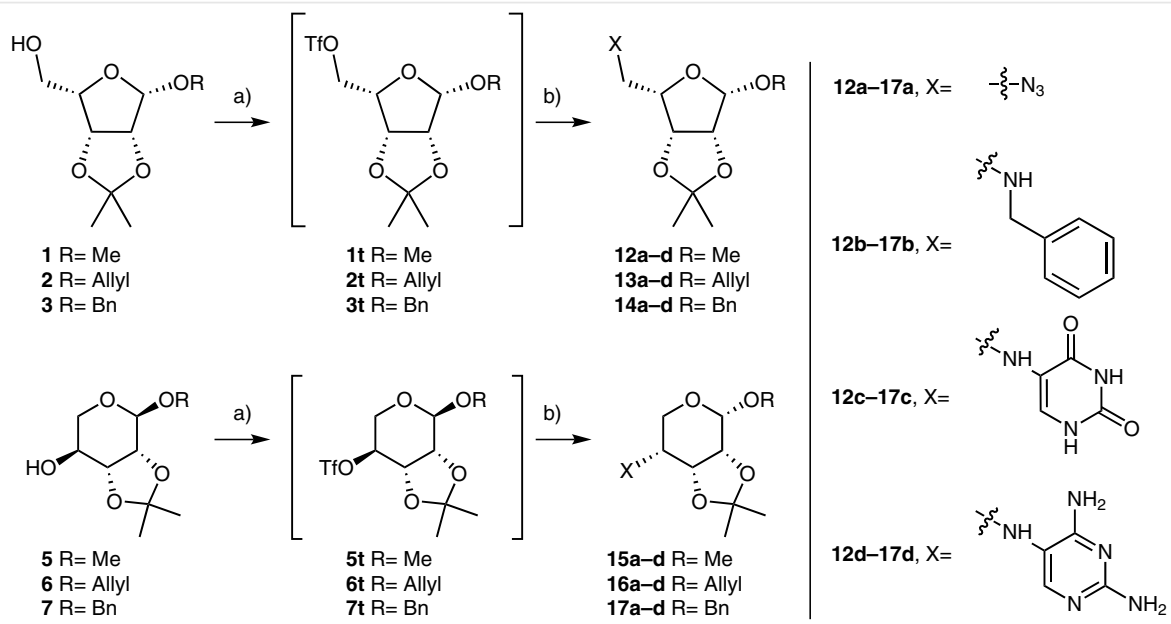

Scheme 3 Generation of the trifluoromethanosulfonyl esters of L-lyxose and subsequent $\mathrm{S}_{\mathrm{N}} 2$ reaction with nucleophiles 8-11. Reagents and conditions: (a) $\mathrm{Tf}_{2} \mathrm{O}$, DMAP, $\mathrm{CH}_{2} \mathrm{Cl}_{2}, \mathrm{Py},-20^{\circ} \mathrm{C}$ to r.t., 4 h; (b) 8-11, DMF, different conditions: see Table 1.

1t-3t and $\mathbf{5 t - 7 t}$ (no purification was attempted due to their instability). The corresponding mesylate leaving groups were not used because they did not react even with sodium azide; whereas the triflate intermediates promptly reacted with the latter nucleophile (Scheme 3 and Table 1, entries 1 and 2). Reaction of the triflate of $\mathbf{1}$ with $\mathbf{1 0}$ over three days at room temperature led to poor yields (entry 3 ). The use of 3.0 equivalents of heterocycles $\mathbf{1 0}$ and $\mathbf{1 1}$ and higher temperature (probably increasing the solubility of the heterocycles and the speed of the reaction) led to higher product yields. The use of $\mathrm{N}, \mathrm{O}$-bis(trimethylsilyl)acetamide (BSA) increased the solubility of 5-aminouracil $\mathbf{1 0}$ and resulted in further improvement of product yields (entry 5), but did not help in the case of $\mathbf{1 1}$ (entry 7).

Reactions of triflates with different nucleophiles at $70{ }^{\circ} \mathrm{C}$ for up to two days generated by-products resulting from the hydrolysis or decomposition of the starting materials. In the $\beta$-L-lyxofuranose series, 2,4,5-triaminopyrimidine 11 produced higher yields than 5-aminouracil $\mathbf{1 0}$ when reacting with the 1t-3t triflates, perhaps reflecting the higher nucleophilicity of the $5-\mathrm{NH}_{2}$ group in 11. For comparison, 5-aminolyxofuranose $\mathbf{1 8}$ was synthesized by hydrogenation of azide 12a (see Scheme 5).

Analyses of the NMR spectra of amines 12c-d, 13c-d and 14d, obtained through $S_{N} 2$ reaction with the corresponding trifluoromethanesulfonates, showed similar features when compared with the corresponding alcohols 1-3, respectively (Table 2 ) and with amine $\mathbf{1 8}$. As expected, the electronic nature of the substituents affected the ${ }^{1} \mathrm{H}$ and ${ }^{13} \mathrm{C}$ NMR shift values; that is, substitution of the hydroxy at $\mathrm{C}(5)$ with an amino group produced an upfield shift of $20 \mathrm{ppm}$ in the ${ }^{13} \mathrm{C}$ NMR spectra and up to $0.6 \mathrm{ppm}$ in the ${ }^{1} \mathrm{H}$ NMR spectra (Table 2 and Table 3, entries 1 and 5). NOESY NMR spectra of the products of the $S_{N} 2$ reaction confirmed the $\beta$-Llyxofuranosyl form of the compounds. Figure 2 illustrates the NMR spectrum of compound 12c. Nuclear Overhauser
Table 1 Reaction Conditions and Products Obtained from the $S_{N} 2$ Reaction Outlined in Scheme 3

\begin{tabular}{llllll}
\hline Entry & Alcohol & Nucleophile & Conditions & Product & $\begin{array}{l}\text { Overall } \\
\text { yield (\%) }\end{array}$ \\
\hline 1 & $\mathbf{1}$ & $\mathbf{8}$ & r.t., $4 \mathrm{~h}$ & $\mathbf{1 2 a}$ & 75 \\
2 & $\mathbf{5}^{\mathrm{b}}$ & $\mathbf{8}$ & r.t., $4 \mathrm{~h}$ & $\mathbf{1 5 a}$ & 68 \\
3 & $\mathbf{1}$ & $\mathbf{1 0}$ & r.t., $3 \mathrm{~d}$ & $\mathbf{1 2 c}$ & $<5$ \\
4 & $\mathbf{1}$ & $\mathbf{1 0}$ & $70^{\circ} \mathrm{C}, 48 \mathrm{~h}$ & $\mathbf{1 2 c}$ & 9 \\
5 & $\mathbf{1}$ & $\mathbf{1 0}$ & $\mathrm{BSA}, 70^{\circ} \mathrm{C}, 48 \mathrm{~h}$ & $\mathbf{1 2 c}$ & 47 \\
6 & $\mathbf{1}$ & $\mathbf{1 1}$ & $70^{\circ} \mathrm{C}, 48 \mathrm{~h}$ & $\mathbf{1 2 d}$ & 56 \\
7 & $\mathbf{1}$ & $\mathbf{1 1}$ & $\mathrm{BSA}, 70^{\circ} \mathrm{C}, 48 \mathrm{~h}$ & $\mathbf{1 2 d}$ & 33 \\
8 & $\mathbf{2}$ & $\mathbf{1 0}$ & $\mathrm{BSA}, 70^{\circ} \mathrm{C}, 48 \mathrm{~h}$ & $\mathbf{1 3 c}$ & 45 \\
9 & $\mathbf{2}$ & $\mathbf{1 1}$ & $70^{\circ} \mathrm{C}, 48 \mathrm{~h}$ & $\mathbf{1 3 d}$ & 48 \\
10 & $\mathbf{3}$ & $\mathbf{1 1}$ & $70^{\circ} \mathrm{C}, 48 \mathrm{~h}$ & $\mathbf{1 4 d}$ & 26 \\
11 & $\mathbf{5}^{\mathrm{b}}$ & $\mathbf{1 0}$ & $\mathrm{BSA}, 70^{\circ} \mathrm{C}, 48 \mathrm{~h}$ & $\mathbf{1 2 c}$ & 5 \\
12 & $\mathbf{5}$ & $\mathbf{1 0}$ & $\mathrm{BSA}, 70^{\circ} \mathrm{C}, 48 \mathrm{~h}$ & $\mathbf{1 5 c}$ & - \\
13 & $\mathbf{5}^{\mathrm{b}}$ & $\mathbf{1 1}$ & $70^{\circ} \mathrm{C}, 48 \mathrm{~h}$ & $\mathbf{1 2 d}$ & 5 \\
14 & $\mathbf{5}$ & $\mathbf{1 1}$ & $70^{\circ} \mathrm{C}, 48 \mathrm{~h}$ & $\mathbf{1 5 d}$ & - \\
15 & $\mathbf{5}$ & $\mathbf{9}$ & $70^{\circ} \mathrm{C}, 24 \mathrm{~h}$ & $\mathbf{1 5 b}$ & 63 \\
16 & $\mathbf{6}$ & $\mathbf{1 0}$ & $\mathrm{BSA}, 70^{\circ} \mathrm{C}, 48 \mathrm{~h}$ & $\mathbf{1 6 c}$ & - \\
17 & $\mathbf{6}$ & $\mathbf{1 1}$ & $70^{\circ} \mathrm{C}, 48 \mathrm{~h}$ & $\mathbf{1 6 d}$ & - \\
\hline
\end{tabular}

a Yields determined after isolation and purification by column chromatography; '-' indicates no reaction.

b Starting material $\mathbf{5}$ was utilized as a mixture of isomers (mixed with $\mathbf{1}$ ).

c By-product 12a was isolated (ca. 5\%) by column chromatography.

effect (nOe) correlations between the proton at the anomeric position with protons at the $\mathrm{C}(2)$ and $\mathrm{C}(4)$ positions confirmed the expected $\beta$-form, in agreement with the starting materials and the anomeric effect. This was consistent with the NOESY spectra of the alcohol starting materials. 
Table $2{ }^{1} \mathrm{H}$ and ${ }^{13} \mathrm{C}$ NMR Chemical Shift Values [ $\delta$, ppm] of Monosaccharides in DMSO- $d_{6}$

\begin{tabular}{|c|c|c|c|c|c|c|c|c|c|c|c|c|c|c|c|}
\hline Entry & Product & Ring $^{a}$ & $\mathrm{R}$ & $x$ & $\mathrm{H}-1$ & $\mathrm{H}-2$ & $\mathrm{H}-3$ & $\mathrm{H}-4$ & $\mathrm{H}-5$ & $C-1$ & $C-2$ & $C-3$ & $C-4$ & $C-5$ & \\
\hline 1 & 1 & Lf & $\mathrm{Me}$ & $\mathrm{OH}$ & 4.81 & 4.49 & 4.70 & 3.85 & $3.51,3.64$ & 106.3 & 84.3 & 79.1 & 80.6 & 58.9 & \multirow{6}{*}{ B-L-Lyxofuranose } \\
\hline 2 & 2 & Lf & Allyl & $\mathrm{OH}$ & 4.95 & 4.53 & 4.72 & 3.90 & $3.55,3.64$ & 104.8 & 84.4 & 79.1 & 80.7 & 58.9 & \\
\hline 3 & 3 & Lf & $\mathrm{Bn}$ & $\mathrm{OH}$ & 5.01 & 4.58 & 4.76 & 3.98 & $3.59,3.68$ & 104.7 & 84.4 & 79.1 & 80.8 & 58.9 & \\
\hline 4 & $19^{b}$ & Lf & $\mathrm{H}$ & $\mathrm{OH}$ & 5.10 & 4.42 & 4.68 & 4.00 & $3.50,3.62$ & 100.0 & 85.6 & 79.5 & 80.0 & 59.2 & \\
\hline 5 & 18 & Lf & Me & $\mathrm{NH}_{2}$ & 4.92 & 4.57 & 4.79 & 4.10 & $2.92,3.15$ & 106.2 & 85.4 & 79.1 & 75.8 & 38.0 & \\
\hline 6 & $12 c$ & Lf & Me & $\mathrm{NH}-\mathrm{U}^{\mathrm{C}}$ & 4.83 & 4.51 & 4.73 & 4.01 & $3.03,3.17$ & 106.3 & 84.4 & 79.5 & 77.8 & 42.8 & \\
\hline 7 & $12 d$ & Lf & Me & NH-Py ${ }^{d}$ & 4.86 & 4.55 & 4.79 & 4.03 & $3.08,3.22$ & 106.4 & 84.4 & 79.3 & 77.4 & 42.7 & \\
\hline 8 & $13 c$ & Lf & Allyl & $\mathrm{NH}-\mathrm{Uc}^{\mathrm{C}}$ & 4.98 & 4.57 & 4.76 & 4.05 & $3.01,3.21$ & 104.8 & 84.6 & 79.5 & 77.8 & 42.8 & \\
\hline 9 & $13 d$ & Lf & Allyl & NH-Py & 4.98 & 4.58 & 4.81 & 4.04 & $3.03,3.16$ & 104.6 & 84.3 & 79.3 & 77.9 & 43.4 & \\
\hline 10 & $14 d$ & Lp & Benzyl & $\mathrm{NH}-\mathrm{Py}^{\mathrm{d}}$ & 5.05 & 4.63 & 4.83 & 4.12 & $3.08,3.22$ & 105.2 & 84.9 & 79.8 & 77.8 & 43.0 & \\
\hline 11 & 5 & Lp & $\mathrm{Me}$ & $\mathrm{OH}$ & 4.59 & 3.95 & 3.95 & 3.58 & $3.38,3.45$ & 99.5 & $77.0^{\mathrm{e}}$ & $74.5^{\mathrm{e}}$ & 66.5 & 62.0 & Iose \\
\hline
\end{tabular}

${ }^{a} \mathrm{Lf}=\beta$-L-lyxofuranoside; $\mathrm{Lp}=\alpha$-L-lyxopyranoside.

${ }^{\mathrm{b}}$ For comparison, compound $\mathbf{1 9}$ was made by hydrogenolysis of $\mathbf{3}$ (see Scheme 5).

' $U=5$-uracil.

d Py $=$ 5-(2,4-diamino)pyrimidine.

e Assignments may be interchanged.

Table $3{ }^{1} \mathrm{H}$ and ${ }^{13} \mathrm{C}$ NMR Chemical Shift Values [ $\delta$, ppm] of Monosaccharides in $\mathrm{CDCl}_{3}$

\begin{tabular}{|c|c|c|c|c|c|c|c|c|c|c|c|c|c|c|c|}
\hline Entry & Product & Ringa & $\mathrm{R}$ & $x$ & $\mathrm{H}-1$ & $\mathrm{H}-2$ & $\mathrm{H}-3$ & $\mathrm{H}-4$ & $\mathrm{H}-5$ & $C-1$ & $C-2$ & $C-3$ & $C-4$ & $C-5$ & \\
\hline 1 & 1 & Lf & Me & $\mathrm{OH}$ & 4.92 & 4.56 & 4.76 & 4.03 & $3.90,3.95$ & 107.2 & 85.3 & 80.4 & 79.4 & 61.2 & $x$ \\
\hline 2 & 2 & Lf & Allyl & $\mathrm{OH}$ & 5.02 & 4.57 & 4.72 & 4.03 & $3.81,3.87$ & 105.1 & 85.0 & 80.0 & 79.4 & 60.7 & \\
\hline 3 & 3 & Lf & $\mathrm{Bn}$ & $\mathrm{OH}$ & 5.15 & 4.71 & 4.81 & 4.13 & $3.94,4.00$ & 105.2 & 85.3 & 80.5 & 79.3 & 61.5 & \\
\hline 4 & $12 a$ & Lf & Me & $\mathrm{N}_{3}$ & 4.91 & 4.57 & 4.70 & 4.08 & $3.50,3.57$ & 106.2 & 84.0 & 78.6 & 77.3 & 48.7 & \\
\hline 5 & 18 & Lf & Me & $\mathrm{NH}_{2}$ & 4.89 & 4.56 & 4.72 & 3.94 & $3.04,3.04$ & 107.1 & 85.2 & 80.7 & 80.1 & 40.9 & anose \\
\hline 6 & 5 & Lp & Me & $\mathrm{OH}$ & 4.64 & 4.12 & 4.23 & 3.81 & $3.71,3.82$ & 99.9 & 74.4 & 76.2 & 67.3 & 63.3 & \\
\hline 7 & 6 & Lp & Allyl & $\mathrm{OH}$ & 4.76 & 4.14 & 4.20 & 3.81 & $3.67,3.75$ & 97.8 & 74.5 & 76.6 & 67.4 & 62.9 & \\
\hline 8 & 7 & Lp & $\mathrm{Bn}$ & $\mathrm{OH}$ & 4.84 & 4.18 & 4.24 & 3.81 & $3.73,3.81$ & 97.3 & 74.5 & 76.5 & 67.3 & 62.8 & $\alpha$-L-Lyxop \\
\hline 9 & $15 a$ & $\mathrm{Rp}$ & Me & $\mathrm{N}_{3}$ & 4.47 & 4.00 & 4.50 & 3.81 & $3.71,3.81$ & 100.9 & 75.3 & 72.9 & 54.9 & 60.2 & \\
\hline 10 & 20 & $\mathrm{Rp}$ & Me & $\mathrm{NH}_{2}$ & 4.37 & 3.94 & 4.34 & 3.21 & $3.71,3.43$ & 101.9 & 75.7 & 75.4 & 49.9 & 65.1 & \\
\hline 11 & $15 b$ & Rp & Me & $\mathrm{NHBn}$ & 4.33 & 3.90 & 4.46 & 3.15 & $3.40,3.85$ & 102.4 & 75.8 & 72.9 & 52.1 & 63.5 & \\
\hline 12 & 21 & Rp & Me & $\mathrm{NHCHO}$ & 4.42 & 4.03 & 4.35 & 4.61 & $3.44,3.82$ & 100.1 & 75.1 & 72.5 & 43.0 & 61.0 & \\
\hline 13 & 22 & $\mathrm{Rp}$ & Me & $\mathrm{NHBz}$ & 4.47 & 4.09 & 4.47 & 4.76 & $3.51,3.97$ & 101.2 & 75.4 & 73.0 & 44.8 & 61.4 & yranose \\
\hline
\end{tabular}

${ }^{\mathrm{a}} \mathrm{Lf}=\beta$-L-lyxofuranoside; $\mathrm{Lp}=\alpha$-L-lyxopyranoside; $\mathrm{Rp}=\beta$-D-ribopyranoside.

In the $\alpha$-L-lyxopyranosyl series, only $\mathrm{NaN}_{3}$ and $\mathrm{BnNH}_{2}$ (Table 1, entries 2 and 15) were successful in reacting with triflate $\mathbf{5 t}$, resulting in inversion of configuration at the $\mathrm{C}(4)$ position by nucleophilic substitution giving D-ribopyranose derivatives $\mathbf{1 5 a}$ and $\mathbf{1 5 b}$, respectively. When reactions were run with heterocycles $\mathbf{1 0}$ and $\mathbf{1 1}$, degradation of triflate $\mathbf{5 t}$ was mostly observed, with only very small amounts of the substituted products being isolated; this reflects the poor nucleophilicity of heterocycles $\mathbf{1 0}$ and $\mathbf{1 1}$. Analysis of the resulting compounds revealed that the reaction products (expected 15c and 15d) had the $\beta$-L-lyxofuranose form instead of the anticipated $\beta$-D-ribopyranose form. NMR comparisons with prepared furanoses showed that these reaction products were the same as $\mathbf{1 2 c}$ and $\mathbf{1 2 d}$. Both pyranose and furanose triflates reacted with good nucleophiles such as azide $\mathbf{8}$ and benzylamine $\mathbf{9}$ (Scheme 4 ) in $\mathrm{S}_{\mathrm{N}} 2$ reactions. Therefore, in these cases, while the isolated major product was the pyranosyl derivative, a minor (furanosyl) product was isolated in small yields or, in some cases, 'lost' during the purification procedures. However, regarding the reac- 
<smiles>CO[C@H]1OCC(O)[C@H]2OC(C)(C)O[C@H]12</smiles>

mixture of isomers

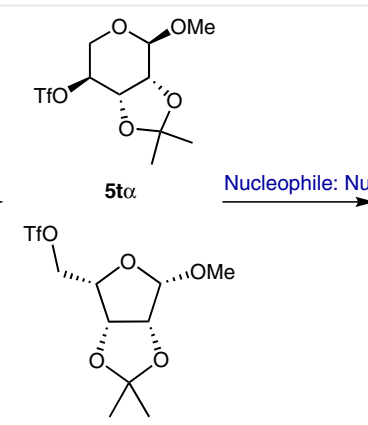

$1+\beta$

(major impurity)<smiles>[Y]C1COC(OC)C2OC(C)(C)OC12</smiles>

$15 \beta$

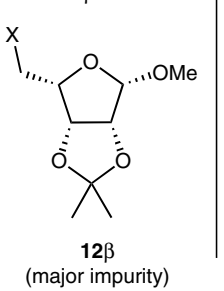

15a and 12a, $X=\quad-\xi-N_{3}$

$12 c, X=$<smiles>CC(C)(C)Nc1c[nH]c(=O)[nH]c1=O</smiles><smiles>CC(C)(C)C(C)(C)C(C)(C)C</smiles>

12d, $X=$<smiles>CNc1cnc(N)nc1N</smiles>

Scheme 4 Reaction scheme for the mixture of isomers of 5 and subsequent $S_{N} 2$ reactions with nucleophiles

tion of pyrimidines $\mathbf{1 0}$ and $\mathbf{1 1}$ with $\mathbf{5 t}$ (mixed with its isomer), it seemed that the minor compound (the furanose form, 1t) is the only isomer able to react with poor nucleophiles (Table 1, entries 11 and 13), whereas the pyranose form $\mathbf{5 t}$ is not reactive with $\mathbf{1 0}$ and $\mathbf{1 1}$. When $\mathrm{S}_{\mathrm{N}} 2$ reactions were repeated starting with pure pyranoses 5-7 and nucleophiles 10 and 11, the expected ribopyranoses 15c/d, $\mathbf{1 6 c} / \mathbf{d}$, and $\mathbf{1 7 c} / \mathbf{d}$ were not formed (Table 1 , entries 12,14 , 16-19), confirming our previous results that only the furanose forms undergo reaction.

We attempted an alternative synthesis of $\mathbf{1 5 c}$ as depicted in Scheme 5. It is known that 5-bromouracil can act as an electrophile and be attacked by amines under different reaction conditions (heat without solvent, ${ }^{14-16}$ reflux, ${ }^{16-18}$ or microwave $\left.{ }^{19}\right)$. Therefore, we prepared aminosugar 20 and reacted it with 5-bromouracil. Unfortunately, this 'in- verse approach' in DMF did not generate the expected compound (15c), but rather led to the $N$-formylated sugar derivative 21. We did not explore this pathway further, but suspect that the 5-bromouracil assisted in the formylation process. Heterocycle-assisted $\mathrm{N}$-formylation reactions under mild conditions have been described utilizing imidazole with primary amines. ${ }^{20}$ Full characterization of $\mathbf{2 1}$ revealed the NMR trends to be consistent with the rest of the $\beta$-Dribopyranose compounds and was comparable to compound 22 prepared via a different route.

To address the question of dealing with mixtures of anomers versus mixtures of furanoses and pyranoses, ${ }^{8}$ we scrutinized the ${ }^{1} \mathrm{H}$ and ${ }^{13} \mathrm{C}$ NMR data of our compounds to find trends in chemical shifts, supported by other NMR spectroscopic techniques that would prove useful in assigning the structures. Table 2 and Table 3 summarize the full charac-<smiles>CO[C@H]1O[C@H](CN)[C@H]2OC(C)(C)O[C@H]12</smiles>

$12 \mathrm{a}$<smiles>CO[C@H]1O[C@H](CN)[C@H]2OC(C)(C)O[C@H]12</smiles>

18<smiles>CC1(C)O[C@H]2[C@@H](CO)O[C@@H](CCO)[C@H]2O1</smiles>

3<smiles>CC(C)CCO</smiles>

19<smiles>COC1OC[C@H](NC(=O)O[C@@H]2[C@@H]3OC(C)(C)O[C@@H]2[C@H](N)CO[C@@H]3OC)[C@H]2OC(C)(C)O[C@H]12</smiles>

Scheme $\mathbf{5}$ Generation of the amines $\mathbf{1 8}$ and $\mathbf{2 0}$ for the 'inverse approach' in which the sugar acts as the nucleophile with a leaving group on the heterocycle. Attempted synthesis of $\mathbf{1 5 c}$. Synthesis of 19 and 22 are shown for comparison. Reagents and conditions: (a) $\mathrm{H}_{2}, \mathrm{Pd} / \mathrm{C}(5 \%), \mathrm{MeOH}$, r.t., $6 \mathrm{~h}$ (18: 95\%; 20: 95\%); (b) $\mathrm{H}_{2}, \mathrm{Pd}(\mathrm{OH})_{2}, \mathrm{MeOH}$, r.t., $20 \mathrm{~h}$ (98\%); (c) 5-bromouracil, DMF, $70{ }^{\circ} \mathrm{C}, 16 \mathrm{~h} \mathrm{(21:56 \%}$ and 15c: not found); (d) $\mathrm{BzCl}$, DIPEA, $\mathrm{CH}_{2} \mathrm{Cl}_{2}$, r.t., $16 \mathrm{~h}(82 \%)$. 

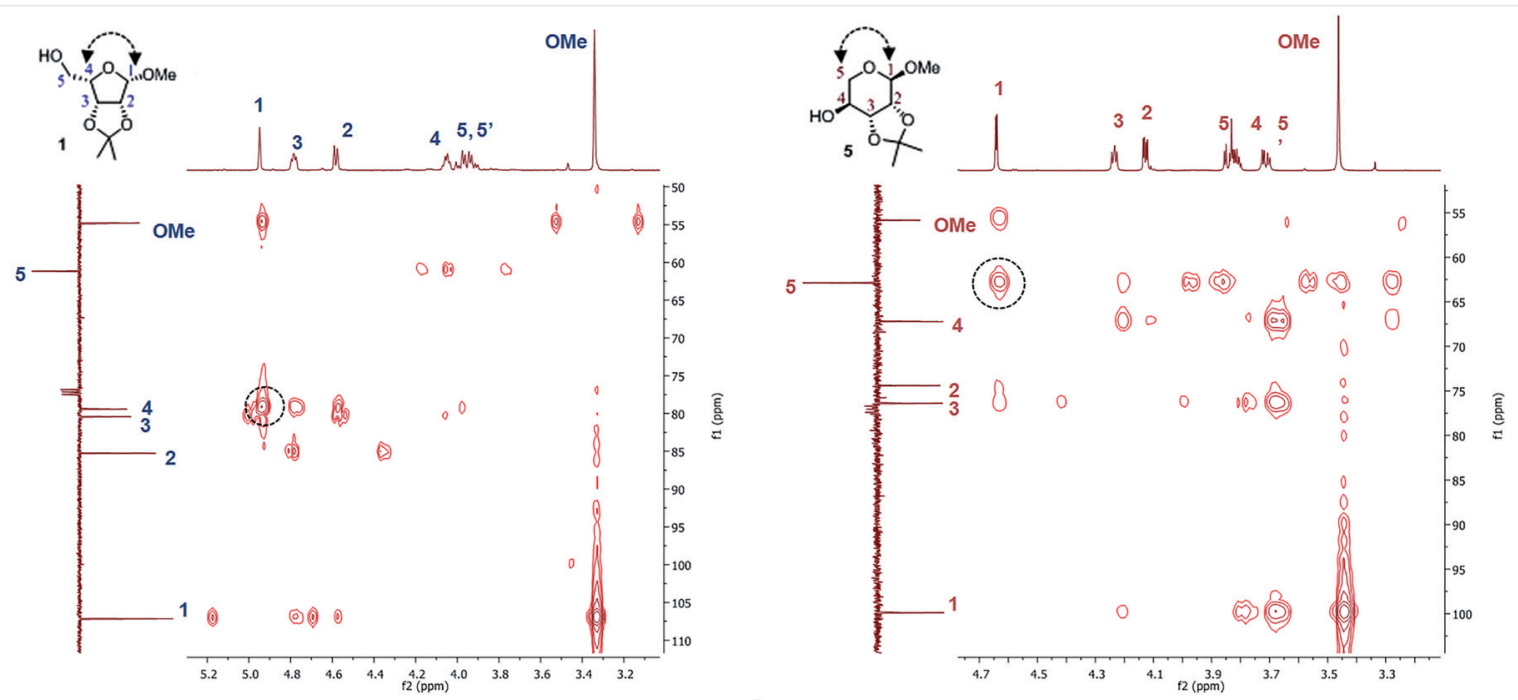

Figure $2 \mathrm{HMBC}\left({ }^{1} \mathrm{H}-{ }^{13} \mathrm{C}, \mathrm{CDCl}_{3}\right)$ spectra of the alcohols $\mathbf{1}$ and $\mathbf{5}$. Correlations highlighted with a dashed circle corroborate unambiguously the configuration of the furanose and pyranose forms, respectively

terization of the sugar derivatives that we have obtained, documenting trends within and between the furanose and pyranose series. Extensive NMR measurements were conducted using the same deuterated solvent (DMSO- $d_{6}$ ) system both for the already published products and related compounds originally reported in $\mathrm{CDCl}_{3}$ (Table 2), and for the heterocycle-attached furanose compounds, which are insoluble in $\mathrm{CDCl}_{3}$ (Table 3). Analyses were carried out by HSQC and COSY NMR spectroscopy of all the structures, in addition to NOESY spectroscopy to confirm the configuration of the pyrano or furano rings and the configuration in the anomeric position (see Figure 3 and the Supporting Information); HMBC spectroscopy was used to corroborate the configuration of the rings (see Figure 2 and the Supporting Information) of some of the starting materials and several products.

In general, the trends in chemical shift for pyranosides versus furanosides (within a sugar series) are consistent, and independent of solvent and substituents in the anomeric position. For example, in ${ }^{1} \mathrm{H}$ NMR spectra for the lyxo series, all shifts except for the $\mathrm{C}(5) \mathrm{H}_{2}$, are more downfield (ca. 0.5-0.3ppm) in the furanose form when compared with the pyranose form. The same trend is observed in the ${ }^{13} \mathrm{C}$ NMR (12-4 ppm) for both the lyxo and the ribo series, as documented in Table 2 (entries 1-3 and entries 11 and 12) and Table 3 (entries 1-3 and entries 6 and 7).

There is also a consistent trend for the different anomers within a given series. The signals for the anomeric position for $\beta$-L-lyxofuranosyl compounds appear around 4.8$5.0 \mathrm{ppm}$ in ${ }^{1} \mathrm{H}$ NMR spectra and $104-107 \mathrm{ppm}$ in ${ }^{13} \mathrm{C}$ NMR spectra; whereas the corresponding values for the $\alpha$-L-lyxopyranosyl forms are consistently more upfield: around 4.6$4.8 \mathrm{ppm}$ in the ${ }^{1} \mathrm{H}$ NMR spectra and below $100 \mathrm{ppm}$ in the

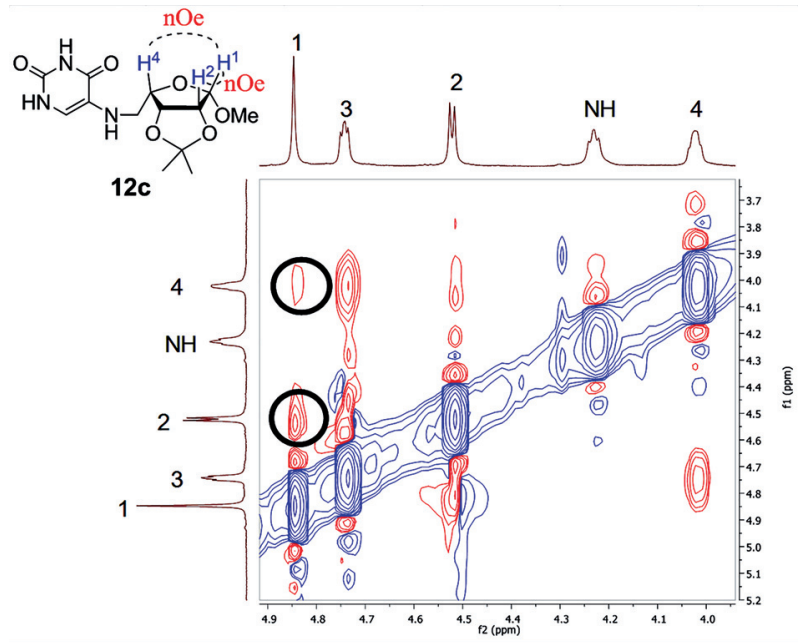

Figure 3 NOESY $\left({ }^{1} \mathrm{H}-{ }^{1} \mathrm{H}\right.$, DMSO- $\left.d_{6}\right)$ spectrum that corroborates the $\beta$ configuration of $12 \mathrm{c}$

${ }^{13} \mathrm{C}$ NMR spectra (Table 2, entries 1-8; Table 3). The substitution of the hydroxyl in the $\mathrm{C}(5)$ position by an amine in the furanose series up-shifted the $\mathrm{CH}_{2}$-signal by $20 \mathrm{ppm}$ in the ${ }^{13} \mathrm{C}$ NMR spectra and by around $0.6 \mathrm{ppm}$ in the ${ }^{1} \mathrm{H}$ NMR spectra (Table 2, entries 1-4 versus 5-10). In the ribopyranose series, substitution in position $\mathrm{C}(4)$ affected the chemical shift values of position $C(4)$ and $C(5)$ depending on the nature of the substituent, as evidenced in Table 3, entries 10 vs. 12 and 13 and entries 10 vs. 11, respectively.

Thus, caution must be exercised to determine whether the compounds are mixtures of furanose/pyranose (in the ribo- or lyxo-series) versus mixtures of anomers (in the ribo- and lyxo-series). ${ }^{8}$ Further NMR spectroscopic (e.g., 
HMBC and NOESY) studies need to be performed to confirm the $\alpha$ - or $\beta$ - versus furanose- or pyranose-configuration of the sugars at hand.

In conclusion, in our attempts to synthesize $\mathrm{N}$-substituted 5-amino-lyxopyranose derivatives, we have demonstrated that only the 5-O-trifluoromethanosulfonate L-lyxofuranoside derivative reacts with 5-aminouracil and 2,4,5-triaminopyrimidine as nucleophiles; $\mathrm{S}_{\mathrm{N}} 2$ reactions with $4-0$ triflate L-lyxopyranoside derivatives with these heterocyclic nucleophiles were unsuccessful. A detailed NMR spectroscopic characterization of both the starting materials and products enabled us to identify trends in chemical shifts for the corresponding lyxosides and ribosides (in the pyrano and furano series versus the $\alpha$ - and $\beta$-anomers). Identifying trends on chemical shifts within each series and also exceptions between them, will be of utility in future investigations. These exceptions point out the potential pitfalls in attempting to recognize mixtures of anomers versus mixtures of furanosides/pyranosides based on trends in chemical shifts alone.

All reagents were obtained from commercial sources and used without purification. Anhydrous solvents were purchased from EMD Chemicals. All experiments were performed under a nitrogen or argon atmosphere. Thin-layer chromatography (TLC) was performed on silica gel $60 \AA \mathrm{F}_{254}$ from Angela Technologies, and visualized under a UV lamp and/or by staining with a solution of phosphomolybdic acid (PMA) in ethanol. Flash column chromatography was performed on silica gel $60 \AA$ with particle size $35-70 \mu \mathrm{m}$ purchased from Acros Organics. NMR spectra were recorded at $20^{\circ} \mathrm{C}$ with a Bruker DRX-600, AV-600 (600 MHz for ${ }^{1} \mathrm{H}$ and $150 \mathrm{MHz}$ for ${ }^{13} \mathrm{C}$ ) or an AV-400 (400 MHz for ${ }^{1} \mathrm{H}$ and $100 \mathrm{MHz}$ for ${ }^{13} \mathrm{C}$ ). Chemical shifts $(\delta)$ are given in parts per million (ppm). ${ }^{1} \mathrm{H}$ and ${ }^{13} \mathrm{C}$ chemical shifts in $\mathrm{CDCl}_{3}$ were referenced to chloroform at $\delta=7.26$ and $77.16 \mathrm{ppm}$, respectively. ${ }^{1} \mathrm{H}$ and ${ }^{13} \mathrm{C}$ chemical shifts in DMSO- $d_{6}$ were referenced to dimethyl sulfoxide at $\delta=$ 2.50 and $39.52 \mathrm{ppm}$, respectively. NMR peak assignments were made based on COSY, HSQC and/or NOESY 2D experiments. Mass spectra were measured with an Agilent ESI-TOF or a ThermoElectron Finnigan LTQ ion trap mass spectrometer.

\section{Synthesis of the Protected Furanoside Sugars}

The protection of the furanose sugars was developed by following the same procedure described by Coleman et al. ${ }^{21}$ L-Lyxose $(1.20 \mathrm{~g}, 8.00$ mmol, 1 equiv) was dissolved in the corresponding freshly distilled alcohol (10 equiv) and anhydrous acetone $(4.70 \mathrm{~mL}, 48.0 \mathrm{mmol}, 8$ equiv). The flask was immersed in an ice bath and concentrated sulfuric acid (3-4 Pasteur pipette drops) was added dropwise. The mixture was stirred at reflux until disappearance of the starting material, as monitored by TLC (3-5 h, depending on the alcohol). The reaction was quenched with saturated aq. $\mathrm{NaHCO}_{3}$ solution and the aqueous solution was extracted three times with EtOAc. The combined organic layers were dried with anhydrous $\mathrm{Na}_{2} \mathrm{SO}_{4}$, filtered and evaporated to dryness. Analysis of the crude material by ${ }^{1} \mathrm{H}$ NMR spectroscopy showed mixtures of furanose and pyranose products up to 1:0.10 ratio (depending on the reaction). The crude reaction mixture was subjected to column chromatography to afford the corresponding pro- tected lyxofuranoside. Traces ( $>5 \%$ ) of the corresponding $2,3-0$-isopropylidene- $\alpha$-L-lyxopiranoside were found in the crude material in all cases.

\section{Methyl 2,3-0-Isopropylidene- $\boldsymbol{\beta}$-L-lyxofuranoside $(\mathbf{1})^{22}$}

Yield: $1.17 \mathrm{~g}$ (72\%); oil; $R_{f}$ (hexanes/EtOAc, 8:2) $=0.18$.

${ }^{1} \mathrm{H}$ NMR $\left(400 \mathrm{MHz}, \mathrm{CDCl}_{3}\right): \delta=4.92(\mathrm{~s}, 1 \mathrm{H}, \mathrm{H}-1), 4.74-4.78(\mathrm{~m}, 1 \mathrm{H}, \mathrm{H}-$ 3), $1.29\left(\mathrm{~s}, 3 \mathrm{H}, \mathrm{CCH}_{3}\right), 4.56(\mathrm{~d}, J=5.9 \mathrm{~Hz}, 1 \mathrm{H}, \mathrm{H}-2), 4.01-4.06(\mathrm{~m}, 1 \mathrm{H}$, H-4), 3.87-3.97 (m, $2 \mathrm{H}, \mathrm{H}-5 \mathrm{a}, \mathrm{H}-5 \mathrm{~b}), 3.32\left(\mathrm{~s}, 3 \mathrm{H}, \mathrm{OCH}_{3}\right), 2.42$ (br s, $1 \mathrm{H}, \mathrm{OH}), 1.45$ (s, $\left.3 \mathrm{H}, \mathrm{CCH}_{3}\right)$.

${ }^{13} \mathrm{C}$ NMR $\left(100 \mathrm{MHz}, \mathrm{CDCl}_{3}\right): \delta=112.8\left(\mathrm{C}\left(\mathrm{CH}_{3}\right)_{2}\right), 107.2(\mathrm{C}-1), 80.4(\mathrm{C}-$ 3), $85.3(\mathrm{C}-2), 79.4(\mathrm{C}-4), 61.2(\mathrm{C}-5), 54.8\left(\mathrm{OCH}_{3}\right), 26.0\left(\mathrm{CCH}_{3}\right), 24.7$ $\left(\mathrm{CCH}_{3}\right)$.

${ }^{1} \mathrm{H}$ NMR $\left(600 \mathrm{MHz}\right.$, DMSO- $\left.d_{6}\right): \delta=4.81(\mathrm{~s}, 1 \mathrm{H}, \mathrm{H}-1), 4.68-4.75(\mathrm{~m}$, $2 \mathrm{H}, \mathrm{H}-3, \mathrm{OH}), 4.49$ (d, J = 5.9 Hz, $1 \mathrm{H}, \mathrm{H}-2$ ), 3.85 (dd, J = 9.6, $5.9 \mathrm{~Hz}$, $1 \mathrm{H}, \mathrm{H}-4), 3.61-3.67$ ( $\mathrm{m}, 1 \mathrm{H}, \mathrm{H}-5 \mathrm{~b}), 3.51-3.57$ (m, $1 \mathrm{H}, \mathrm{H}-5 \mathrm{a}), 3.22(\mathrm{~s}$, $\left.3 \mathrm{H}, \mathrm{OCH}_{3}\right), 1.34\left(\mathrm{~s}, 3 \mathrm{H}, \mathrm{CCH}_{3}\right), 1.24\left(\mathrm{~s}, 3 \mathrm{H}, \mathrm{CCH}_{3}\right)$.

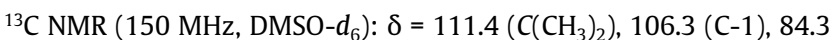
(C-2), 80.6 (C-4), $79.1(\mathrm{C}-3), 58.9(\mathrm{C}-5), 53.9\left(\mathrm{OCH}_{3}\right), 26.0\left(\mathrm{CCH}_{3}\right), 24.7$ $\left(\mathrm{CCH}_{3}\right)$.

ESI(+)-MS: $m / z$ calcd. for $\mathrm{C}_{9} \mathrm{H}_{17} \mathrm{O}_{5}[\mathrm{M}+\mathrm{H}]^{+}:$205.11; found: 205.11 .

Data in agreement with the literature ${ }^{22}$ (ent-1).

\section{Allyl 2,3-0-Isopropylidene- $\boldsymbol{\beta}$-L-lyxofuranoside (2)}

Yield: $884 \mathrm{mg}$ (48\%); oil; $R_{f}$ (hexanes/EtOAc, 8:2) $=0.25$.

${ }^{1} \mathrm{H}$ NMR $\left(600 \mathrm{MHz}, \mathrm{CDCl}_{3}\right.$ ): $\delta=5.81$ (dddd, $J=17.5,10.4,6.4,5.5 \mathrm{~Hz}$, $\left.1 \mathrm{H}, \mathrm{CH}=\mathrm{CH}_{2}\right), 5.21\left(\mathrm{~d}, J=17.2 \mathrm{~Hz}, 1 \mathrm{H}, \mathrm{CH}=\mathrm{CH}_{2}\right.$-trans $), 5.12(\mathrm{~d}, J=$ $10.4 \mathrm{~Hz}, 1 \mathrm{H}, \mathrm{CH}=\mathrm{CH}_{2}-\mathrm{cis}$ ), $5.02(\mathrm{~s}, 1 \mathrm{H}, \mathrm{H}-1), 4.72$ (dd, $J=5.7,4.3 \mathrm{~Hz}$, $1 \mathrm{H}, \mathrm{H}-3), 4.57$ (d, J = 5.7 Hz, $1 \mathrm{H}, \mathrm{H}-2), 4.09$ (dd, $J=12.3,5.5 \mathrm{~Hz}, 1 \mathrm{H}$, $\left.\mathrm{OCH} \mathrm{HCH}=\mathrm{CH}_{2}\right), 4.03(\mathrm{dd}, J=9.4,5.1 \mathrm{~Hz}, 1 \mathrm{H}, \mathrm{H}-4), 3.90(\mathrm{dd}, J=12.3$, $\left.6.4 \mathrm{~Hz}, 1 \mathrm{H}, \mathrm{OCHHCH}=\mathrm{CH}_{2}\right), 3.81-3.87(\mathrm{~m}, 2 \mathrm{H}, \mathrm{H}-5 \mathrm{a}, \mathrm{H}-5 \mathrm{~b}), 2.75$ (br. s, $1 \mathrm{H}, \mathrm{OH}), 1.39$ (s, $\left.3 \mathrm{H}, \mathrm{CCH}_{3}\right), 1.24\left(\mathrm{~s}, 3 \mathrm{H}, \mathrm{CCH}_{3}\right)$.

${ }^{13} \mathrm{C}$ NMR $\left(150 \mathrm{MHz}, \mathrm{CDCl}_{3}\right): \delta=133.7\left(\mathrm{CH}=\mathrm{CH}_{2}\right), 117.4\left(\mathrm{CH}=\mathrm{CH}_{2}\right)$,

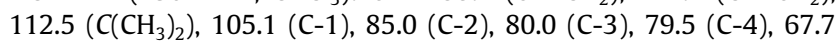
$\left(\mathrm{OCH}_{2} \mathrm{CH}=\mathrm{CH}_{2}\right), 60.7(\mathrm{C}-5), 25.7\left(\mathrm{CCH}_{3}\right), 24.4\left(\mathrm{CCH}_{3}\right)$.

${ }^{1} \mathrm{H}$ NMR $\left(600 \mathrm{MHz}\right.$, DMSO- $\left.d_{6}\right): \delta=5.89$ (dddd, $J=16.2,10.8,5.9$, $5.0 \mathrm{~Hz}, 1 \mathrm{H}, \mathrm{CH}=\mathrm{CH}_{2}$ ), 5.25 (dd, $J=17.3,1.7 \mathrm{~Hz}, 1 \mathrm{H}, \mathrm{CH}=\mathrm{CH}_{2}$-trans), 5.12 (dd, $J=10.4,1.6 \mathrm{~Hz}, 1 \mathrm{H}, \mathrm{CH}=\mathrm{CH}_{2}$-cis), 4.95 (s, $\left.1 \mathrm{H}, \mathrm{H}-1\right), 4.70-$ 4.75 (m, $2 \mathrm{H}, \mathrm{H}-3, \mathrm{OH}), 4.53$ (d, $J=5.5 \mathrm{~Hz}, 1 \mathrm{H}, \mathrm{H}-2$ ), 4.09 (dd, $J=13.3$, $\left.5.0 \mathrm{~Hz}, 1 \mathrm{H}, \mathrm{OCHHCH}=\mathrm{CH}_{2}\right), 3.94(\mathrm{dd}, J=13.3,5.9 \mathrm{~Hz}, 1 \mathrm{H}, \mathrm{OCH}-$ $\left.\mathrm{HCH}=\mathrm{CH}_{2}\right), 3.88-3.92(\mathrm{~m}, 1 \mathrm{H}, \mathrm{H}-4), 3.64(\mathrm{dt}, J=11.2,5.6 \mathrm{~Hz}, 1 \mathrm{H}, \mathrm{H}-$ 5b), 3.51-3.57 (m, $1 \mathrm{H}, \mathrm{H}-5 \mathrm{a}$ ), 1.34 (s, $3 \mathrm{H}, \mathrm{CCH}_{3}$ ), 1.24 (s, $3 \mathrm{H}, \mathrm{CCH}_{3}$ ).

${ }^{13} \mathrm{C}$ NMR $\left(150 \mathrm{MHz}\right.$, DMSO- $\left.d_{6}\right): \delta=134.6\left(\mathrm{CH}=\mathrm{CH}_{2}\right), 116.7\left(\mathrm{CH}=\mathrm{CH}_{2}\right)$,

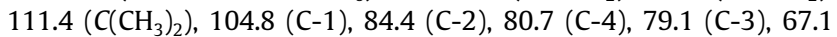
$\left(\mathrm{OCH}_{2} \mathrm{CH}=\mathrm{CH}_{2}\right), 58.9(\mathrm{C}-5), 26.0\left(\mathrm{CCH}_{3}\right), 24.7\left(\mathrm{CCH}_{3}\right)$.

ESI(+)-MS: $m / z$ calcd. for $\mathrm{C}_{11} \mathrm{H}_{19} \mathrm{O}_{5}[\mathrm{M}+\mathrm{H}]^{+}:$231.12; found: 231.12 .

ESI(+)-MS: $m / z$ calcd. for $\mathrm{C}_{11} \mathrm{H}_{18} \mathrm{NaO}_{5}[\mathrm{M}+\mathrm{Na}]^{+}$: 253.10; found: 253.10.

Data in agreement with the literature. ${ }^{8}$

\section{Benzyl 2,3-0-Isopropylidene- $\boldsymbol{\beta}$-L-lyxofuranoside (3) ${ }^{23}$}

Yield: $828 \mathrm{mg}$ (37\%); yellow oil; $R_{f}$ (hexanes/EtOAc, 9:1) $=0.10$.

${ }^{1} \mathrm{H}$ NMR $\left(600 \mathrm{MHz}, \mathrm{CDCl}_{3}\right): \delta=7.28-7.37(\mathrm{~m}, 5 \mathrm{H}, \mathrm{H}-\mathrm{Bn}), 5.15(\mathrm{~s}, 1 \mathrm{H}$, $\mathrm{H}-1), 4.81$ (dd, $J=5.6,3.8 \mathrm{~Hz}, 1 \mathrm{H}, \mathrm{H}-3), 4.66-4.71(\mathrm{~m}, 2 \mathrm{H}, \mathrm{CHHPh}, \mathrm{H}-$ 2), 4.50 (d, J = $11.7 \mathrm{~Hz}, 1 \mathrm{H}, \mathrm{CHHPh}), 4.11-4.15(\mathrm{~m}, 1 \mathrm{H}, \mathrm{H}-4), 4.00$ (dd, $J=11.5,4.9 \mathrm{~Hz}, 1 \mathrm{H}, \mathrm{H}-5 \mathrm{~b}), 3.94$ (dd, $J=11.7,4.5 \mathrm{~Hz}, 1 \mathrm{H}, \mathrm{H}-5 \mathrm{a}), 1.82$ (br. s, $1 \mathrm{H}, \mathrm{OH}), 1.47$ (s, $\left.3 \mathrm{H}, \mathrm{CCH}_{3}\right), 1.31\left(\mathrm{~s}, 3 \mathrm{H}, \mathrm{CCH}_{3}\right)$. 
${ }^{13} \mathrm{C}$ NMR (150 MHz, $\mathrm{CDCl}_{3}$ ): $\delta=137.2$ (C-Bn), 128.5 (C-Bn), 128.1 (C$\mathrm{Bn}), 127.9$ (C-Bn), $112.7\left(\mathrm{C}\left(\mathrm{CH}_{3}\right)_{2}\right), 105.2(\mathrm{C}-1), 85.3(\mathrm{C}-2), 80.5$ (C-3), $79.3(\mathrm{C}-4), 69.0\left(\mathrm{OCH}_{2} \mathrm{Ph}\right), 61.5(\mathrm{C}-5), 25.8\left(\mathrm{CCH}_{3}\right), 24.4\left(\mathrm{CCH}_{3}\right)$.

${ }^{1} \mathrm{H}$ NMR (600 MHz, DMSO- $d_{6}$ ): $\delta=7.28-7.39$ (m, $\left.5 \mathrm{H}, \mathrm{H}-\mathrm{Bn}\right), 5.01(\mathrm{~s}$, $1 \mathrm{H}, \mathrm{H}-1$ ), 4.76 (dd, J = 5.9, $5.0 \mathrm{~Hz}, 1 \mathrm{H}, \mathrm{H}-3$ ), 4.76 (br. s, $1 \mathrm{H}, \mathrm{OH}$ ), 4.62 (d, $J=11.9 \mathrm{~Hz}, 1 \mathrm{H}, \mathrm{CHHPh}), 4.58$ (d, $J=5.9 \mathrm{~Hz}, 1 \mathrm{H}, \mathrm{H}-2), 4.46$ (d, $J=$ $11.9 \mathrm{~Hz}, 1 \mathrm{H}, \mathrm{CHHPh}$ ), 3.98 (dd, $J=9.3,5.8 \mathrm{~Hz}, 1 \mathrm{H}, \mathrm{H}-4), 3.68(\mathrm{dt}, J=$ 11.2, $5.6 \mathrm{~Hz}, 1 \mathrm{H}, \mathrm{H}-5 \mathrm{~b}), 3.56-3.62$ (m, $1 \mathrm{H}, \mathrm{H}-5 \mathrm{a}), 1.35$ (s, $3 \mathrm{H}, \mathrm{CCH}_{3}$ ), $1.25\left(\mathrm{~s}, 3 \mathrm{H}, \mathrm{CCH}_{3}\right)$.

${ }^{13} \mathrm{C}$ NMR (150 MHz, DMSO- $d_{6}$ ): $\delta=137.6$ (C-Bn), 128.3 (C-Bn), 127.8 (C-Bn), $127.6(\mathrm{C}-\mathrm{Bn}), 111.4\left(\mathrm{C}\left(\mathrm{CH}_{3}\right)_{2}\right), 104.7(\mathrm{C}-1), 84.4(\mathrm{C}-2), 80.8(\mathrm{C}-$ 4), 79.1 (C-3), $67.9\left(\mathrm{OCH}_{2} \mathrm{Ph}\right), 58.9(\mathrm{C}-5), 26.0\left(\mathrm{CCH}_{3}\right), 24.6\left(\mathrm{CCH}_{3}\right)$,

ESI(+)-MS: $m / z$ calcd. for $\mathrm{C}_{15} \mathrm{H}_{21} \mathrm{O}_{5}[\mathrm{M}+\mathrm{H}]^{+}:$281.33; found: 281.33 .

Data in agreement with the literature ${ }^{23}$ (ent-3).

\section{Methyl $\boldsymbol{\alpha}$-L-Lyxopyranoside (4a) (4,6,7 $^{4}$}

To a methanolic $\mathrm{HCl}$ solution $(0.5 \% \mathrm{w} / \mathrm{v})$, prepared in situ by the reaction of acetyl chloride $(0.1 \mathrm{~mL}, 0.7 \mathrm{mmol})$ in anhydrous $\mathrm{MeOH}(7.5$ $\mathrm{mL}$ ), was added L-lyxose (1.5 g, $10 \mathrm{mmol}, 1.0$ equiv) under an argon atmosphere. The resulting suspension was heated under reflux for $4 \mathrm{~h}$ until disappearance of L-lyxose. The cooled solution was neutralized with Amberlist ${ }^{\circledR}$ basic resin IRA 400 (2 g) with stirring. The resin was filtered and washed several times with $\mathrm{MeOH}$. The filtrate and washings were combined and evaporated to give a colorless syrup, which was recrystallized in EtOAc to afford a mixture of isomers where the major compound was $\mathbf{4 a}$.

Yield: $1.64 \mathrm{~g}$ (70\%); white amorphous solid; $R_{f}\left(\mathrm{CH}_{2} \mathrm{Cl}_{2} / \mathrm{MeOH}, 9: 1\right)=$ 0.15 .

${ }^{1} \mathrm{H}$ NMR (400 MHz, DMSO- $\left.d_{6}\right): \delta=4.76-4.81(\mathrm{~m}, 2 \mathrm{H}, 2 \times \mathrm{OH}), 4.65(\mathrm{~d}$, $J=5.5 \mathrm{~Hz}, 1 \mathrm{H}, \mathrm{OH}), 4.39-4.44(\mathrm{~m}, 1 \mathrm{H}, \mathrm{H}-1), 3.55-3.61$ (m, $3 \mathrm{H}, \mathrm{C}-2, \mathrm{C}-$ 4, OH), 3.36-3.50 (m, $2 \mathrm{H}, \mathrm{H}-3, \mathrm{H}-5 \mathrm{~b}), 3.25\left(\mathrm{~s}, 3 \mathrm{H}, \mathrm{OCH}_{3}\right), 3.22-3.27$ ( $\mathrm{m}, 1 \mathrm{H}, \mathrm{H}-5 \mathrm{a})$.

${ }^{13} \mathrm{C}$ NMR (100 MHz, DMSO- $d_{6}$ ): $\delta=101.7$ (C-1), 71.3 (C-3), 69.8 (C-2), 66.9 (C-4), 63.1 (C-5), $54.7\left(\mathrm{OCH}_{3}\right)$.

Data in agreement with the literature. ${ }^{4,6,7}$

\section{Synthesis of the Protected Pyranose Sugars $4 b$ and $4 c$}

L-Lyxose (1.5 g, $10 \mathrm{mmol}, 1$ equiv) was dissolved in the corresponding freshly distilled alcohol (allyl or benzyl alcohol, $100 \mathrm{mmol}, 10$ equiv). The solution was immersed in an ice bath and $\mathrm{H}_{2} \mathrm{SO}_{4}(6.1 \mathrm{~mol} \%)$ was added dropwise. The solution was warmed to r.t., heated to reflux for $3 \mathrm{~h}$ and stirred overnight at r.t. Reaction progress was monitored by TLC (90:10, $\left.\mathrm{CH}_{2} \mathrm{Cl}_{2} / \mathrm{MeOH}\right)$ and the reaction was quenched with Amberlyst A-26(OH) resin (2 g). The mixture was shaken for $30 \mathrm{~min}$, filtered, and the resin was washed with $\mathrm{MeOH}$. The combined filtrate and washings was evaporated and the residue was washed several times with diethyl ether ( $30 \mathrm{~mL}$ each) to remove the excess alcohol. The residue was subjected to column chromatography $\left(\mathrm{CH}_{2} \mathrm{Cl}_{2} / \mathrm{MeOH}\right.$, 9:1 and hexanes/EtOAc, 2:8, respectively) to afford products $\mathbf{4 b}$ and 4c, respectively.

\section{Allyl $\boldsymbol{\alpha}$-L-Lyxopyranoside (4b) ${ }^{10}$}

Yield: $1.34 \mathrm{~g}$ (71\%); white amorphous solid; $R_{f}\left(\mathrm{CH}_{2} \mathrm{Cl}_{2} / \mathrm{MeOH}, 9: 1\right)=$ 0.40 .

${ }^{1} \mathrm{H}$ NMR $\left(600 \mathrm{MHz}\right.$, DMSO- $\left.d_{6}\right): \delta=5.88$ (dddd, $J=17.1,10.4,5.6$, $\left.4.8 \mathrm{~Hz}, 1 \mathrm{H}, \mathrm{CH}=\mathrm{CH}_{2}\right), 5.25\left(\mathrm{~d}, J=17.1 \mathrm{~Hz}, 1 \mathrm{H}, \mathrm{CH}=\mathrm{CH}_{2}\right.$-trans $), 5.14$ (d, $\left.J=10.4 \mathrm{~Hz}, 1 \mathrm{H}, \mathrm{CH}=\mathrm{CH}_{2}-\mathrm{cis}\right), 4.76-4.81(\mathrm{~m}, 2 \mathrm{H}, 2 \times \mathrm{OH}), 4.65(\mathrm{~d}, J=$
$5.5 \mathrm{~Hz}, 1 \mathrm{H}, \mathrm{OH}$ ), $4.56(\mathrm{~d}, J=2.8 \mathrm{~Hz}, 1 \mathrm{H}, \mathrm{H}-1), 4.09$ (dd, $J=13.3,4.8 \mathrm{~Hz}$, $\left.1 \mathrm{H}, \mathrm{OCHHCH}=\mathrm{CH}_{2}\right), 3.91$ (dd, $J=13.3,5.6 \mathrm{~Hz}, 1 \mathrm{H}, \mathrm{OCHHCH}=\mathrm{CH}_{2}$ ), 3.55-3.61 (m, $2 \mathrm{H}, \mathrm{H}-2, \mathrm{H}-4), 3.49$ (dd, $J=10.8,4.9 \mathrm{~Hz}, 1 \mathrm{H}, \mathrm{H}-5 \mathrm{~b})$, 3.44-3.47 (m, $1 \mathrm{H}, \mathrm{H}-3$ ), 3.26 (dd, J=10.8, $9.4 \mathrm{~Hz}, 1 \mathrm{H}, \mathrm{H}-5 \mathrm{a}$ ).

${ }^{13} \mathrm{C}$ NMR (150 MHz, DMSO- $\left.d_{6}\right): \delta=134.9\left(\mathrm{CH}=\mathrm{CH}_{2}\right), 116.6\left(\mathrm{CH}=\mathrm{CH}_{2}\right)$, 99.8 (C-1), $71.3(\mathrm{C}-3), 69.9(\mathrm{C}-2), 67.4\left(\mathrm{OCH}_{2} \mathrm{CH}=\mathrm{CH}_{2}\right), 66.9(\mathrm{C}-4), 63.4$ (C-5).

ESI(+)-MS: $m / z$ calcd for $\mathrm{C}_{8} \mathrm{H}_{15} \mathrm{O}_{5}[\mathrm{M}+\mathrm{H}]^{+}:$191.09; found: 191.09 .

ESI(-)-MS: $m / z$ calcd for $\mathrm{C}_{8} \mathrm{H}_{13} \mathrm{O}_{5}[\mathrm{M}-\mathrm{H}]^{-}:$: 189.08; found: 189.08 .

ESI(+)-MS: $m / z$ calcd for $\mathrm{C}_{8} \mathrm{H}_{14} \mathrm{O}_{5} \mathrm{Na}[\mathrm{M}+\mathrm{Na}]^{+}:$213.07; found: 213.07 .

ESI(-)-MS: $m / z$ calcd for $\mathrm{C}_{8} \mathrm{H}_{14} \mathrm{O}_{5} \mathrm{Cl}[\mathrm{M}+\mathrm{Cl}]^{-}: 225.05$; found: 225.05 .

Data in agreement with the literature ${ }^{10}$ (ent-4b).

Benzyl $\boldsymbol{\alpha}$-L-Lyxopyranoside (4c) $)^{9,12,24}$

Yield: $1.44 \mathrm{~g}(60 \%)$; white amorphous solid; $R_{f}$ (hexanes/EtOAc, $\left.2: 8\right)=$ 0.15 .

${ }^{1} \mathrm{H}$ NMR (600 MHz, DMSO- $d_{6}$ ): $\delta=7.26-7.39$ (m, $\left.5 \mathrm{H}, \mathrm{H}-\mathrm{Bn}\right), 4.80$ (d, $J=5.0 \mathrm{~Hz}, 2 \mathrm{H}, 2 \times \mathrm{OH}), 4.66(\mathrm{~d}, J=5.6 \mathrm{~Hz}, 1 \mathrm{H}, \mathrm{OH}), 4.60(\mathrm{~s}, 1 \mathrm{H}, \mathrm{H}-1)$, 4.60 (d, $J=12.0 \mathrm{~Hz}, 1 \mathrm{H}, \mathrm{CHHPh}), 4.41$ (d, $J=12.0 \mathrm{~Hz}, 1 \mathrm{H}, \mathrm{CHHPh})$, 3.56-3.63 (m, $2 \mathrm{H}, \mathrm{H}-2, \mathrm{H}-4$ ), 3.55 (dd, J = 10.0, $5.2 \mathrm{~Hz}, 1 \mathrm{H}, \mathrm{H}-5 \mathrm{~b}$ ), 3.48 (dd, $J=8.3,5.5,3.0 \mathrm{~Hz}, 1 \mathrm{H}, \mathrm{H}-3), 3.31$ (dd, $J=10.0,10.0 \mathrm{~Hz}, 1 \mathrm{H}, \mathrm{H}-5 \mathrm{a}$ ). ${ }^{13} \mathrm{C}$ NMR (150 MHz, DMSO- $d_{6}$ ): $\delta=138.0(C-B n), 128.3$ (C-Bn), 127.7 (C-Bn), 127.5 (C-Bn), 99.8 (C-1), 71.2 (C-3), 69.9 (C-2 or C-4), 68.2 $\left(\mathrm{OCH}_{2} \mathrm{Ph}\right), 66.8$ (C-4 or C-2), $63.4(\mathrm{C}-5)$.

ESI(+)-MS: $m / z$ calcd for $\mathrm{C}_{12} \mathrm{H}_{17} \mathrm{O}_{5}[\mathrm{M}+\mathrm{H}]^{+}: 241.11$; found: 241.11 .

ESI(+)-MS: $m / z$ calcd for $\mathrm{C}_{12} \mathrm{H}_{16} \mathrm{NaO}_{5}[\mathrm{M}+\mathrm{Na}]^{+}: 263.09$; found: 263.09 . ESI(-)-MS: $m / z$ calcd for $\mathrm{C}_{12} \mathrm{H}_{15} \mathrm{O}_{5}[\mathrm{M}-\mathrm{H}]^{-}:$:239.09; found: 239.09 . ESI(-)-MS: $m / z$ calcd for $\mathrm{C}_{12} \mathrm{H}_{16} \mathrm{O}_{5} \mathrm{Cl}[\mathrm{M}+\mathrm{Cl}]^{-}: 275.07$; found: 275.07 . Data in agreement with the literature ${ }^{9,12,24}$ (ent-4c).

\section{General Procedure for the 2,3-Di-O-isopropylidene Protection of Pyranoses}

To the corresponding 1- $O$-protected pyranoside ( $5 \mathrm{mmol}$, 1 equiv), was added anhydrous acetone (1.83 mL, $215 \mathrm{mmol} 5$ equiv), 2,2-dimethoxypropane ( $1.85 \mathrm{~mL}, 15 \mathrm{mmol}, 3$ equiv) and concentrated $\mathrm{HCl}$ (3-5 Pasteur pipette drops). The solution was stirred for $18 \mathrm{~h}$ at r.t. The reaction was quenched with a saturated solution $\mathrm{NaHCO}_{3}$ and extracted with $\mathrm{CH}_{2} \mathrm{Cl}_{2}$ (3 times). The combined organic layers were dried with anhydrous $\mathrm{Na}_{2} \mathrm{SO}_{4}$, filtered, and solvent was removed in vacuo. Analysis of the ${ }^{1} \mathrm{H}$ NMR spectrum of the crude product showed mixtures of pyranose and furanose products up to 1:0.25 ratios (depending on the reaction). The products were purified and isolated by flash silica column chromatography with hexanes/EtOAc as the eluent.

\section{Methyl 2,3-0-Isopropylidene- $\boldsymbol{\alpha}$-L-lyxopyranoside (5) $\mathbf{5}^{4,6,7,10}$}

Yield: $520 \mathrm{mg}$ (51\%); yellow oil; $R_{f}$ (hexanes/EtOAc, $\left.1: 1\right)=0.55$.

${ }^{1} \mathrm{H}$ NMR $\left(600 \mathrm{MHz}, \mathrm{CDCl}_{3}\right): \delta=4.64(\mathrm{~d}, J=2.6 \mathrm{~Hz}, 1 \mathrm{H}, \mathrm{H}-1), 4.23$ (dd, $J$ $=6.0,4.8 \mathrm{~Hz}, 1 \mathrm{H}, \mathrm{H}-3), 4.12(\mathrm{dd}, J=6.0,2.7 \mathrm{~Hz}, 1 \mathrm{H}, \mathrm{H}-2), 3.79-3.86$ (m, $2 \mathrm{H}, \mathrm{H}-5 \mathrm{~b}, \mathrm{H}-4), 3.71$ (dd, $J=11.2,4.6 \mathrm{~Hz}, 1 \mathrm{H}, \mathrm{H}-5 \mathrm{a}), 3.46(\mathrm{~s}, 3 \mathrm{H}$, $\left.\mathrm{OCH}_{3}\right), 2.97(\mathrm{~d}, J=8.0 \mathrm{~Hz}, 1 \mathrm{H}, \mathrm{OH}), 1.51\left(\mathrm{~s}, 3 \mathrm{H}, \mathrm{CCH}_{3}\right), 1.35(\mathrm{~s}, 3 \mathrm{H}$, $\left.\mathrm{CCH}_{3}\right)$.

${ }^{13} \mathrm{C}$ NMR (150 MHz, $\left.\mathrm{CDCl}_{3}\right): \delta=109.7\left(\mathrm{C}_{\left(\mathrm{CH}_{3}\right)}\right), 99.9(\mathrm{C}-1), 76.2(\mathrm{C}-3)$, 74.4 (C-2), 67.3 (C-4), $63.3(\mathrm{C}-5), 56.0\left(\mathrm{OCH}_{3}\right), 27.6\left(\mathrm{CCH}_{3}\right), 25.7$ $\left(\mathrm{CCH}_{3}\right)$. 
${ }^{1} \mathrm{H}$ NMR (400 MHz, DMSO- $\left.d_{6}\right): \delta=5.18(\mathrm{~d}, J=5.4 \mathrm{~Hz}, 1 \mathrm{H}, \mathrm{OH}), 4.59(\mathrm{~d}$, $J=1.9 \mathrm{~Hz}, 1 \mathrm{H}, \mathrm{H}-1), 3.90-3.97$ (m, $2 \mathrm{H}, \mathrm{H}-3, \mathrm{H}-2), 3.54-3.62(\mathrm{~m}, 1 \mathrm{H}$, H-4), 3.45 (dd, $J=11.5,4.4 \mathrm{~Hz}, 1 \mathrm{H}, \mathrm{H}-5 \mathrm{~b}), 3.35-3.40$ (m, $1 \mathrm{H}, \mathrm{H}-5 \mathrm{a})$, $3.31\left(\mathrm{~s}, 3 \mathrm{H}, \mathrm{OCH}_{3}\right), 1.41\left(\mathrm{~s}, 3 \mathrm{H}, \mathrm{CCH}_{3}\right), 1.27\left(\mathrm{~s}, 3 \mathrm{H}, \mathrm{CCH}_{3}\right)$.

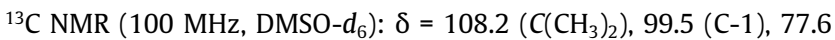
(C-3 or C-2), 74.5 (C-2 or C-3), $66.5(\mathrm{C}-4), 62.0(\mathrm{C}-5), 54.9\left(\mathrm{OCH}_{3}\right), 28.0$ $\left(\mathrm{CCH}_{3}\right), 26.2\left(\mathrm{CCH}_{3}\right)$.

Data in agreement with the literature $\mathrm{r}^{4,6,7,10}$ (ent-5).

\section{Allyl 2,3-0-Isopropylidene- $\alpha$-L-lyxopyranoside $(6)^{4,6,7,10}$} Yield: $655 \mathrm{mg}$ (57\%); yellow oil; $R_{f}$ (hexanes/EtOAc, 1:1) $=0.70$.

${ }^{1} \mathrm{H}$ NMR $\left(600 \mathrm{MHz}, \mathrm{CDCl}_{3}\right): \delta=5.87$ (ddt, $J=16.3,10.4,1.2 \mathrm{~Hz}, 1 \mathrm{H}$, $\mathrm{CH}=\mathrm{CH}_{2}$ ), 5.29 (dd, $J=16.3,1.4 \mathrm{~Hz}, 1 \mathrm{H}, \mathrm{CH}=\mathrm{CH}_{2}$-trans), 5.20 (d, $J=$ $10.4 \mathrm{~Hz}, 1 \mathrm{H}, \mathrm{CH}=\mathrm{CH}_{2}$-cis), 4.76-4.79 (m, $1 \mathrm{H}, \mathrm{H}-1$ ), 4.25 (ddd, $J=12.8$, $\left.5.3,1.2 \mathrm{~Hz}, 1 \mathrm{H}, \mathrm{OCHHCH}=\mathrm{CH}_{2}\right), 4.20(\mathrm{t}, J=5.3 \mathrm{~Hz}, 1 \mathrm{H}, \mathrm{H}-3), 4.12-4.15$ $(\mathrm{m}, 1 \mathrm{H}, \mathrm{H}-2), 4.05$ (ddd, $J=12.8,6.2,1.2 \mathrm{~Hz}, 1 \mathrm{H}, \mathrm{OCHHCH}=\mathrm{CH}_{2}$ ), 3.78-3.83 (m, $1 \mathrm{H}, \mathrm{H}-4), 3.75$ (dd, $J=11.6,3.8 \mathrm{~Hz}, 1 \mathrm{H}, \mathrm{H}-5 \mathrm{~b}$ ), 3.67 (dd, $J=11.6,5.9 \mathrm{~Hz}, 1 \mathrm{H}, \mathrm{H}-5 \mathrm{a}), 3.38-3.44(\mathrm{~m}, 1 \mathrm{H}, \mathrm{OH}), 1.47\left(\mathrm{~s}, 3 \mathrm{H}, \mathrm{CCH}_{3}\right)$, $1.32\left(\mathrm{~s}, 3 \mathrm{H}, \mathrm{CCH}_{3}\right)$.

${ }^{13} \mathrm{C}$ NMR $\left(150 \mathrm{MHz}, \mathrm{CDCl}_{3}\right): \delta=133.5\left(\mathrm{CH}=\mathrm{CH}_{2}\right), 118.0\left(\mathrm{CH}=\mathrm{CH}_{2}\right)$, $109.5\left(\mathrm{C}\left(\mathrm{CH}_{3}\right)_{2}\right), 97.8(\mathrm{C}-1), 76.7(\mathrm{C}-3), 74.6(\mathrm{C}-2), 68.8\left(\mathrm{OCH}_{2} \mathrm{CH}=\mathrm{CH}_{2}\right)$, $67.4(\mathrm{C}-4), 62.9(\mathrm{C}-5), 27.7\left(\mathrm{CCH}_{3}\right), 25.7\left(\mathrm{CCH}_{3}\right)$.

ESI(+)-MS: $m / z$ calcd for $\mathrm{C}_{11} \mathrm{H}_{19} \mathrm{O}_{5}[\mathrm{M}+\mathrm{H}]^{+}: 231.12$; found: 231.12 .

ESI(+)-MS: $m / z$ calcd for $\mathrm{C}_{11} \mathrm{H}_{18} \mathrm{O}_{5} \mathrm{Na}[\mathrm{M}+\mathrm{Na}]^{+}: 253.10$; found: 253.10 . ${ }^{1} \mathrm{H}$ NMR $\left(600 \mathrm{MHz}\right.$, DMSO- $\left.d_{6}\right): \delta=5.85-5.95\left(\mathrm{~m}, 1 \mathrm{H}, \mathrm{CH}=\mathrm{CH}_{2}\right), 5.27-$ $5.32\left(\mathrm{~m}, 1 \mathrm{H}, \mathrm{CH}=\mathrm{CH}_{2}\right), 5.13-5.21\left(\mathrm{~m}, 2 \mathrm{H}, \mathrm{CH}=\mathrm{CH}_{2}, \mathrm{OH}\right), 4.67-4.71(\mathrm{~m}$, $1 \mathrm{H}, \mathrm{H}-1), 4.15\left(\mathrm{dt}, J=16.2,8.1 \mathrm{~Hz}, 1 \mathrm{H}, \mathrm{OCHHCH}=\mathrm{CH}_{2}\right), 3.93-4.04(\mathrm{~m}$, $\left.3 \mathrm{H}, \mathrm{OCH} H \mathrm{CH}=\mathrm{CH}_{2}, \mathrm{H}-2, \mathrm{H}-3\right), 3.54-3.62(\mathrm{~m}, 1 \mathrm{H}, \mathrm{H}-4), 3.39-3.49(\mathrm{~m}$, $2 \mathrm{H}, \mathrm{H}-5 \mathrm{a}, \mathrm{H}-5 \mathrm{~b}), 1.41$ (s, $\left.3 \mathrm{H}, \mathrm{CCH}_{3}\right), 1.28\left(\mathrm{~s}, 3 \mathrm{H}, \mathrm{CCH}_{3}\right)$.

${ }^{13} \mathrm{C}$ NMR (150 MHz, DMSO-d $\left.d_{6}\right): \delta=134.4\left(\mathrm{CH}=\mathrm{CH}_{2}\right), 116.8\left(\mathrm{CH}=\mathrm{CH}_{2}\right)$,

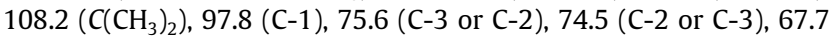
$\left(\mathrm{OCH}_{2} \mathrm{CH}=\mathrm{CH}_{2}\right), 66.5(\mathrm{C}-4), 62.4(\mathrm{C}-5), 28.0\left(\mathrm{CCH}_{3}\right), 26.2\left(\mathrm{CCH}_{3}\right)$.

Data in agreement with the literature $\mathrm{e}^{4,6,7,10}$ (ent-6).

\section{Benzyl 2,3-0-Isopropylidene- $\boldsymbol{\alpha}$-L-lyxopyranoside (7) $)^{9,12,24}$}

Yield: $700 \mathrm{mg}$ (50\%); white amorphous solid; $R_{f}$ (hexanes/EtOAc, $8: 2)=0.20$.

${ }^{1} \mathrm{H}$ NMR (600 MHz, $\mathrm{CDCl}_{3}$ ): $\delta=7.29-7.39(\mathrm{~m}, 5 \mathrm{H}, \mathrm{H}-\mathrm{Bn}), 4.84(\mathrm{~d}, J=$ $2.5 \mathrm{~Hz}, 1 \mathrm{H}, \mathrm{H}-1), 4.81$ (d, $J=11.8 \mathrm{~Hz}, 1 \mathrm{H}, \mathrm{CHHPh}), 4.57$ (d, $J=11.8 \mathrm{~Hz}$, $1 \mathrm{H}, \mathrm{CHHPh}$ ), 4.23 (d, J = 5.4 Hz, $1 \mathrm{H}, \mathrm{H}-3$ ), 4.18 (dd, J = 6.0, $2.5 \mathrm{~Hz}, 1 \mathrm{H}$, H-2), 3.78-3.84 (m, $2 \mathrm{H}, \mathrm{H}-4, \mathrm{H}-5 \mathrm{~b}$ ), 3.73 (dd, $J=11.4,5.8 \mathrm{~Hz}, 1 \mathrm{H}, \mathrm{H}-$ 5a), 3.00 (br s, $1 \mathrm{H}, \mathrm{OH}$ ), 1.46 (s, $\left.3 \mathrm{H}, \mathrm{CCH}_{3}\right), 1.34\left(\mathrm{~s}, 3 \mathrm{H}, \mathrm{CCH}_{3}\right.$ ).

${ }^{13} \mathrm{C}$ NMR (150 MHz, $\mathrm{CDCl}_{3}$ ): $\delta=136.6$ (C-Bn), 128.5 (C-Bn), 128.1 (C$\mathrm{Bn}), 127.9$ (C-Bn), $109.5\left(\mathrm{C}\left(\mathrm{CH}_{3}\right)_{2}\right), 97.3(\mathrm{C}-1), 74.5(\mathrm{C}-2), 76.5(\mathrm{C}-3)$, $69.6\left(\mathrm{CH}_{2} \mathrm{Ph}\right), 67.3(\mathrm{C}-4), 62.8(\mathrm{C}-5), 27.4\left(\mathrm{CCH}_{3}\right), 25.6\left(\mathrm{CCH}_{3}\right)$.

Data in agreement with the literature ${ }^{9,12,24}$ (ent-7).

\section{General Procedure for the Triflate Formation Reaction}

Pyridine (0.10 mL, $1.20 \mathrm{mmol}$ ) and 4-(dimethylamino)pyridine (6.00 $\mathrm{mg}, 5 \mathrm{~mol} \%$ ) in anhydrous $\mathrm{CH}_{2} \mathrm{Cl}_{2}(5 \mathrm{~mL})$ was treated slowly with $1 \mathrm{M}$ solution of trifluoromethanesulfonic anhydride in $\mathrm{CH}_{2} \mathrm{Cl}_{2}(1.30 \mathrm{~mL}$, $1.30 \mathrm{mmol}$ ) at $-20^{\circ} \mathrm{C}$ under argon atmosphere. The reaction mixture was stirred at $-20^{\circ} \mathrm{C}$ for $5 \mathrm{~min}$. The corresponding alcohol (1.00 mmol) in $\mathrm{CH}_{2} \mathrm{Cl}_{2}(2 \mathrm{~mL})$ was added via a cannula, the mixture was stirred at $-20^{\circ} \mathrm{C}$ for $15 \mathrm{~min}$ and then warmed to r.t. The reaction was monitored by TLC until disappearance of the starting material (30 min to $2 \mathrm{~h}$ ) indicated completion of the reaction. The mixture was poured into a mixture of $25 \mathrm{~mL}$ ice-water and $10 \mathrm{~mL} \mathrm{CH}_{2} \mathrm{Cl}_{2}$ and the organic layer was separated. The aqueous phase was extracted with $\mathrm{CH}_{2} \mathrm{Cl}_{2}$ three times. The combined organic layers were washed with water and brine, dried with anhydrous $\mathrm{Na}_{2} \mathrm{SO}_{4}$, filtered and evaporated to give the intermediate triflate product as pale-yellow gummy solid. The product was used without further purification.

\section{General Procedure for the $S_{\mathbf{N}} 2$ Reaction; Method $A$}

The crude trifluoromethanesulfonate intermediate $(1.00 \mathrm{mmol})$ was dissolved in freshly distilled DMF $(10 \mathrm{~mL})$, then the corresponding nucleophile ( $\mathbf{8}$ or $\mathbf{9}, 3.00 \mathrm{mmol}$ ) was added. The suspension was stirred at r.t. overnight, then the reaction mixture was evaporated to dryness. The residue was dissolved in a mixture of $\mathrm{CH}_{2} \mathrm{Cl}_{2}$ and water. The organic layer was separated and washed with water and brine, dried with anhydrous $\mathrm{MgSO}_{4}$, filtered and evaporated to obtain an oily residue, which, on purification by silica gel flash chromatography, afforded the expected product.

\section{Methyl 5-Azido-5-deoxy-2,3-O-isopropylidene- $\beta$-L-lyxofurano- side (12a)}

Yield: $172 \mathrm{mg}$ (overall yield $75 \%$ ); oil; $R_{f}$ (Hexanes/EtOAc, 9:1) $=0.58$. ${ }^{1} \mathrm{H}$ NMR $\left(600 \mathrm{MHz}, \mathrm{CDCl}_{3}\right): \delta=4.91(\mathrm{~s}, 1 \mathrm{H}, \mathrm{H}-1), 4.70$ (dd, $J=5.9$, $3.7 \mathrm{~Hz}, 1 \mathrm{H}, \mathrm{H}-3$ ), 4.57 (d, $J=5.9 \mathrm{~Hz}, 1 \mathrm{H}, \mathrm{H}-2$ ), 4.08 (ddd, $J=7.6,5.2$, $3.9 \mathrm{~Hz}, 1 \mathrm{H}, \mathrm{H}-4), 3.57(\mathrm{dt}, J=12.8,6.4 \mathrm{~Hz}, 1 \mathrm{H}, \mathrm{H}-5 \mathrm{~b}), 3.47-3.52(\mathrm{~m}$, $1 \mathrm{H}, \mathrm{H}-5 \mathrm{a}), 3.34\left(\mathrm{~s}, 1 \mathrm{H}, \mathrm{OCH}_{3}\right), 1.46\left(\mathrm{~s}, 1 \mathrm{H}, \mathrm{CCH}_{3}\right), 1.31\left(\mathrm{~s}, 1 \mathrm{H}, \mathrm{CCH}_{3}\right)$.

${ }^{13} \mathrm{C}$ NMR $\left(150 \mathrm{MHz}, \mathrm{CDCl}_{3}\right): \delta=111.9\left(\mathrm{C}\left(\mathrm{CH}_{3}\right)_{2}\right), 106.2(\mathrm{C}-1), 84.0(\mathrm{C}-$ 2), 78.6 (C-3), $77.3(\mathrm{C}-4), 53.7\left(\mathrm{OCH}_{3}\right), 48.7(\mathrm{C}-5), 25.0\left(\mathrm{CCH}_{3}\right), 23.8$ $\left(\mathrm{CCH}_{3}\right)$.

ESI(+)-MS: $m / z$ calcd. for $\mathrm{C}_{9} \mathrm{H}_{15} \mathrm{~N}_{3} \mathrm{O}_{4} \mathrm{Na}[\mathrm{M}+\mathrm{Na}]^{+}$: 252.10; found: 252.10 .

\section{Methyl 4-Azido-4-deoxy-2,3-O-isopropylidene- $\beta$-D-ribopyrano- side (15a) $)^{4,6,7}$}

Yield: $156 \mathrm{mg}$ (overall yield $68 \%$ ); oil; $R_{f}$ (hexanes/EtOAc, 9:1) $=0.56$. ${ }^{1} \mathrm{H}$ NMR $\left(600 \mathrm{MHz}, \mathrm{CDCl}_{3}\right): \delta=4.48-4.52(\mathrm{~m}, 1 \mathrm{H}, \mathrm{H}-3), 4.47$ (d, $J=$ $3.8 \mathrm{~Hz}, 1 \mathrm{H}, \mathrm{H}-1$ ), 4.00 (dd, J = 6.3, 3.8 Hz, $1 \mathrm{H}, \mathrm{H}-2), 3.78-3.84(\mathrm{~m}, 2 \mathrm{H}$, $\mathrm{H}-4, \mathrm{H}-5 \mathrm{~b}), 3.69-3.74$ (m, $1 \mathrm{H}, \mathrm{H}-5 \mathrm{a}), 3.41$ (s, $\left.3 \mathrm{H}, \mathrm{OCH}_{3}\right), 1.53$ (s, $3 \mathrm{H}$, $\left.\mathrm{CCH}_{3}\right), 1.35\left(\mathrm{~s}, 3 \mathrm{H}, \mathrm{CCH}_{3}\right)$.

${ }^{13} \mathrm{C}$ NMR $\left(150 \mathrm{MHz}, \mathrm{CDCl}_{3}\right): \delta=110.8\left(\mathrm{C}\left(\mathrm{CH}_{3}\right)_{2}\right), 100.9(\mathrm{C}-1), 75.3(\mathrm{C}-$ 2), 72.9 (C-3), 60.2 (C-5), $56.4\left(\mathrm{OCH}_{3}\right), 54.9$ (C-4), $26.9\left(\mathrm{CCH}_{3}\right), 25.6$ $\left(\mathrm{CCH}_{3}\right)$.

ESI(+)-MS: $m / z$ calcd for $\mathrm{C}_{9} \mathrm{H}_{16} \mathrm{~N}_{3} \mathrm{O}_{4}[\mathrm{M}+\mathrm{H}]^{+}: 230.11$; found: 230.11 .

ESI(+)-MS: $m / z$ calcd. for $\mathrm{C}_{9} \mathrm{H}_{15} \mathrm{~N}_{3} \mathrm{O}_{4} \mathrm{Na}[\mathrm{M}+\mathrm{Na}]^{+}$: 252.10; found: 252.10.

Data in agreement with the literature $e^{4,6,7}$

\section{Methyl 4-Benzylamino-4-deoxy-2,3-0-isopropylidene- $\beta$-D-ribopy- ranoside (15b)}

Yield: $184 \mathrm{mg}$ (overall yield $63 \%$ ); oil; $R_{f}$ (hexane/EtOAc, 13:7) $=0.66$. ${ }^{1} \mathrm{H}$ NMR $\left(600 \mathrm{MHz}, \mathrm{CDCl}_{3}\right): \delta=7.28-7.36(\mathrm{~m}, 4 \mathrm{H}, \mathrm{H}-\mathrm{Bn}), 7.22-7.27$ (m, $1 \mathrm{H}, \mathrm{H}-\mathrm{Bn}), 4.46$ (dd, $J=5.4,3.8 \mathrm{~Hz}, 1 \mathrm{H}, \mathrm{H}-3), 4.33$ (d, $J=5.3 \mathrm{~Hz}$, $1 \mathrm{H}, \mathrm{H}-1$ ), 3.88-3.92 (m, $2 \mathrm{H}, \mathrm{NCHHPh}, \mathrm{H}-2$ ), 3.81-3.87 (m, $2 \mathrm{H}, \mathrm{H}-5 \mathrm{~b}$, $\mathrm{NCHHPh}), 3.45\left(\mathrm{~s}, 3 \mathrm{H}, \mathrm{OCH}_{3}\right), 3.37-3.43(\mathrm{~m}, 1 \mathrm{H}, \mathrm{H}-5 \mathrm{a}), 3.15$ (ddd, $J=$ 11.0, 5.6, 3.6 Hz, $1 \mathrm{H}, \mathrm{H}-4), 1.35$ (s, $\left.3 \mathrm{H}, \mathrm{CCH}_{3}\right), 1.23$ (s, $\left.3 \mathrm{H}, \mathrm{CCH}_{3}\right)$.

${ }^{13} \mathrm{C}$ NMR (150 MHz, $\left.\mathrm{CDCl}_{3}\right): \delta=140.2(\mathrm{C}-\mathrm{Bn}), 128.5$ (C-Bn), $128.1(\mathrm{C}-$ $\mathrm{Bn}), 127.2(\mathrm{C}-\mathrm{Bn}), 109.7\left(\mathrm{C}\left(\mathrm{CH}_{3}\right)_{2}\right), 102.4(\mathrm{C}-1), 75.8(\mathrm{C}-2), 72.9(\mathrm{C}-3)$, $63.5(\mathrm{C}-5), 56.6\left(\mathrm{OCH}_{3}\right), 52.1(\mathrm{C}-4), 51.1\left(\mathrm{PhCH}_{2} \mathrm{NH}\right), 27.6\left(\mathrm{CCH}_{3}\right), 25.8$ $\left(\mathrm{CCH}_{3}\right)$. 
ESI(+)-HRMS: $m / z$ calcd for $\mathrm{C}_{16} \mathrm{H}_{24} \mathrm{NO}_{4}[\mathrm{M}+\mathrm{H}]^{+}:$294.1700; found: 294.1701.

\section{General Procedure for the $S_{\mathrm{N}} \mathbf{2}$ Reaction; Method B}

The crude trifluoromethanesulfonate intermediate $(1.00 \mathrm{mmol})$ was dissolved in distilled DMF (10 mL), then the corresponding nucleophile (10 or $\mathbf{1 1}, 3.00 \mathrm{mmol}$ ) was added. The suspension was stirred at $70{ }^{\circ} \mathrm{C}$ until consumption of the starting material was observed (reaction monitored by TLC), then the reaction mixture was evaporated to dryness. The residue was filtered through a pad of Celite ${ }^{\circledR}$ and silica. The pad was washed several times with EtOAc/MeOH (9:1) to avoid dissolving the excess of nucleobase that did not react during the reaction. The filtrate and washings were combined and evaporated. The residue was purified by silica gel flash chromatography to afford the expected product.

\section{Methyl 5-Deoxy-2,3-0-isopropylidene-5-(uracil-5-ylamino)- $\beta$-L- lyxofuranoside (12c)}

Yield: $147 \mathrm{mg}$ (overall yield 47\%); yellow amorphous solid; $R_{f}$ $($ EtOAc $/ \mathrm{MeOH}, 9: 1)=0.66$.

${ }^{1} \mathrm{H}$ NMR (600 MHz, DMSO- $d_{6}$ ): $\delta=11.16(\mathrm{~s}, 1 \mathrm{H}, \mathrm{NH}$-uracil), 10.18 (s, $1 \mathrm{H}, \mathrm{NH}$-uracil), 6.47 (d, J = 3.4 Hz, $1 \mathrm{H}, \mathrm{CH}$-uracil), 4.83 (s, $1 \mathrm{H}, \mathrm{H}-1$ ), 4.71-4.74 (m, $1 \mathrm{H}, \mathrm{H}-3), 4.51$ (d, $J=5.9 \mathrm{~Hz}, 1 \mathrm{H}, \mathrm{H}-2), 4.21-4.23(\mathrm{~m}$, $\left.1 \mathrm{H}, \mathrm{NHCH}_{2}\right), 4.00-4.03(\mathrm{~m}, 1 \mathrm{H}, \mathrm{H}-4), 3.21\left(\mathrm{~s}, 3 \mathrm{H}, \mathrm{OCH}_{3}\right), 3.16-3.19$ (m, $1 \mathrm{H}, \mathrm{H}-5 \mathrm{~b}), 2.95-3.06$ (m, $1 \mathrm{H}, \mathrm{H}-5 \mathrm{a}), 1.36$ (s, $\left.3 \mathrm{H}, \mathrm{CCH}_{3}\right), 1.25$ (s, $3 \mathrm{H}, \mathrm{CCH}_{3}$ ).

${ }^{13} \mathrm{C}$ NMR (150 MHz, DMSO- $d_{6}$ ): $\delta=161.4$ (CO-uracil), 149.5 (CO-uracil), 123.7 (C-uracil), 113.7 (CH-uracil), $111.7\left(C\left(\mathrm{CH}_{3}\right)_{2}\right), 106.3(\mathrm{C}-1)$, 84.4 (C-2), 79.5 (C-3), 77.8 (C-4), $54.0\left(\mathrm{OCH}_{3}\right), 42.8(\mathrm{C}-5), 26.0\left(\mathrm{CCH}_{3}\right)$, $24.7\left(\mathrm{C}\left(\mathrm{CH}_{3}\right)\right)$.

ESI(+)-HRMS: $m / z$ calcd for $\mathrm{C}_{13} \mathrm{H}_{20} \mathrm{~N}_{3} \mathrm{O}_{6}[\mathrm{M}+\mathrm{H}]^{+}: 314.1347$; found: 314.1352.

ESI(-)-HRMS: $m / z$ calcd for $\mathrm{C}_{13} \mathrm{H}_{18} \mathrm{~N}_{3} \mathrm{O}_{6}[\mathrm{M}-\mathrm{H}]^{-}:$:312.1201; found: 312.1199 .

ESI(+)-HRMS: $m / z$ calcd for $\mathrm{C}_{13} \mathrm{HN}_{3} \mathrm{O}_{6} \mathrm{Na}[\mathrm{M}+\mathrm{Na}]^{+}: 336.1166$; found: 336.1168.

\section{Methyl 5-Deoxy-5-(2,4-diaminopyrimidin-5-ylamino)-2,3-0-iso- propylidene- $\beta$-L-lyxofuranoside (12d)}

Yield: $174 \mathrm{mg}$ (overall yield, 56\%); brown-orange amorphous solid; $R_{f}$ $(\mathrm{EtOAc} / \mathrm{MeOH}, 95: 5)=0.65$.

${ }^{1} \mathrm{H}$ NMR (150 MHz, DMSO- $d_{6}$ ): $\delta=7.39$ (br. s, $2 \mathrm{H}, \mathrm{NH}_{2}$-pyrimidine), 7.05 (br. s, $2 \mathrm{H}, \mathrm{NH}_{2}$-pyrimidine), 7.01 (s, $1 \mathrm{H}, \mathrm{CH}$-pyrimidine), 4.86 (s, $1 \mathrm{H}, \mathrm{H}-1), 4.79$ (dd, $J=5.6,3.7 \mathrm{~Hz}, 1 \mathrm{H}, \mathrm{H}-3), 4.68-4.72(\mathrm{~m}, 1 \mathrm{H}, \mathrm{NH})$, $4.55(\mathrm{~d}, J=5.9 \mathrm{~Hz}, 1 \mathrm{H}, \mathrm{H}-2), 4.03(\mathrm{dd}, J=9.6,5.9 \mathrm{~Hz}, \mathrm{H}-4), 3.21(\mathrm{~s}, 3 \mathrm{H}$, $\left.\mathrm{OCH}_{3}\right), 3.20-3.23$ (m, H-5b), 3.05-3.12 (m, $\left.1 \mathrm{H}, \mathrm{H}-5 \mathrm{a}\right), 1.37$ (s, $3 \mathrm{H}$, $\left.\mathrm{CCH}_{3}\right), 1.27\left(\mathrm{~s}, 3 \mathrm{H}, \mathrm{CCH}_{3}\right)$.

${ }^{13} \mathrm{C}$ NMR $\left(150 \mathrm{MHz}\right.$, DMSO- $d_{6}$ ): $\delta=159.0$ (C-pyrimidine), 151.2 (C-pyrimidine), 121.0 (C-pyrimidine), 118.3 (CH-pyrimidine), 111.8 $\left(\mathrm{C}\left(\mathrm{CH}_{3}\right)_{2}\right), 106.4(\mathrm{C}-1), 84.4(\mathrm{C}-2), 79.3(\mathrm{C}-3), 77.4(\mathrm{C}-4), 54.1\left(\mathrm{OCH}_{3}\right)$, $42.7(\mathrm{C}-5), 26.0\left(\mathrm{CCH}_{3}\right), 24.8\left(\mathrm{CCH}_{3}\right)$.

ESI(+)-HRMS: $m / z$ calcd for $\mathrm{C}_{13} \mathrm{H}_{22} \mathrm{~N}_{5} \mathrm{O}_{4}[\mathrm{M}+\mathrm{H}]^{+}$: 312.1666 ; found: 312.1670.

ESI(+)-HRMS: $m / z$ calcd for $\mathrm{C}_{13} \mathrm{H}_{21} \mathrm{~N}_{5} \mathrm{O}_{4} \mathrm{Na}[\mathrm{M}+\mathrm{Na}]^{+}$: 334.1486; found: 334.1485 .
Allyl 5-Deoxy-2,3-O-isopropylidene-5-(uracil-5-ylamino)- $\beta$-L-lyxofuranoside (13c)

Yield: $152 \mathrm{mg}$ (overall yield 45\%); pale-yellow amorphous solid; $R_{f}$ $\left(\mathrm{CH}_{2} \mathrm{Cl}_{2} / \mathrm{MeOH}, 95: 5\right)=0.20$.

${ }^{1} \mathrm{H}$ NMR (600 MHz, DMSO- $d_{6}$ ): $\delta=11.16$ (s, $1 \mathrm{H}, \mathrm{NH}$-uracil), 10.55 (s, $1 \mathrm{H}, \mathrm{NH}$-uracil), 6.49 (d, J = 5.4 Hz, $1 \mathrm{H}, \mathrm{CH}$-uracil), 5.83-5.92 (m, $1 \mathrm{H}$, $\left.\mathrm{CH}=\mathrm{CH}_{2}\right), 5.24\left(\mathrm{~d}, J=17.3 \mathrm{~Hz}, 1 \mathrm{H}, \mathrm{CH}=\mathrm{CH}_{2}\right.$-trans $), 5.15(\mathrm{~d}, J=10.2 \mathrm{~Hz}$, $\left.1 \mathrm{H}, \mathrm{CH}=\mathrm{CH}_{2}-\mathrm{cis}\right), 4.98(\mathrm{~s}, 1 \mathrm{H}, \mathrm{H}-1), 4.76(\mathrm{dd}, J=10.9,7.1 \mathrm{~Hz}, 1 \mathrm{H}, \mathrm{H}-3)$, $4.57(\mathrm{~d}, J=5.8 \mathrm{~Hz}, 1 \mathrm{H}, \mathrm{H}-2), 4.21-4.25(\mathrm{~m}, 1 \mathrm{H}, \mathrm{NH}), 4.00-4.09(\mathrm{~m}$, $\left.2 \mathrm{H}, \mathrm{H}-4, \mathrm{OCH}_{2} \mathrm{CH}=\mathrm{CH}_{2}\right), 392-3.98(\mathrm{~m}, 1 \mathrm{H}, \mathrm{H}-5 \mathrm{~b}), 3.18-3.25(\mathrm{~m}, 1 \mathrm{H}$, H-5a), 2.98-3.04 (m, $1 \mathrm{H}, \mathrm{CH} H \mathrm{NH}), 1.38\left(\mathrm{~s}, 3 \mathrm{H}, \mathrm{CCH}_{3}\right), 1.26(\mathrm{~s}, 3 \mathrm{H}$, $\left.\mathrm{CCH}_{3}\right)$.

${ }^{13} \mathrm{C}$ NMR (150 MHz, DMSO- $d_{6}$ ): $\delta=161.4$ (CO-uracil), 149.4 (CO-uracil), $134.6\left(\mathrm{CH}=\mathrm{CH}_{2}\right), 123.7$ (C-uracil), $116.9\left(\mathrm{CH}=\mathrm{CH}_{2}\right), 113.7(\mathrm{CH}$-ura-

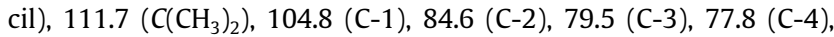
$67.3\left(\mathrm{OCH}_{2} \mathrm{CH}=\mathrm{CH}_{2}\right), 42.8(\mathrm{C}-5), 26.0\left(\mathrm{CCH}_{3}\right), 24.7\left(\mathrm{CCH}_{3}\right)$.

ESI(+)-HRMS: $m / z$ calcd. for $\mathrm{C}_{15} \mathrm{H}_{22} \mathrm{~N}_{3} \mathrm{O}_{6}[\mathrm{M}+\mathrm{H}]^{+}: 340.1509$; found: 340.1507.

ESI(+)-HRMS: $m / z$ calcd. for $\mathrm{C}_{15} \mathrm{H}_{21} \mathrm{~N}_{3} \mathrm{NaO}_{6}[\mathrm{M}+\mathrm{Na}]^{+}$: 362.1328; found: 362.1325 .

Allyl 5-Deoxy-5-(2,4-diaminopyrimidin-5-ylamino)-2,3-0-isopropylidene- $\beta$-L-lyxofuranoside (13d)

Yield: $162 \mathrm{mg}$ (overall yield 48\%); brown-orange solid; mp 146$148{ }^{\circ} \mathrm{C} ; R_{f}\left(\mathrm{CH}_{2} \mathrm{Cl}_{2} / \mathrm{MeOH}, 9: 1\right)=0.23 ; R_{f}\left(\mathrm{CH}_{2} \mathrm{Cl}_{2} / \mathrm{MeOH}, 9: 1\right)=0.20$.

${ }^{1} \mathrm{H}$ NMR (600 MHz, DMSO- $d_{6}$ ): $\delta=7.40$ (s, $1 \mathrm{H}, \mathrm{CH}$-pyrimidine), 6.34 (br. s, $2 \mathrm{H}, \mathrm{NH}_{2}$ ), 5.82-5.93 (m, $1 \mathrm{H}, \mathrm{CH}=\mathrm{CH}_{2}$ ), 5.49 (br. s, $2 \mathrm{H}, \mathrm{NH}_{2}$ ), $5.24\left(\mathrm{dd}, J=17.2,1.7 \mathrm{~Hz}, \mathrm{CH}=\mathrm{CH}_{2}\right.$-trans), $5.14(\mathrm{dd}, J=10.4,1.5 \mathrm{~Hz}, 1 \mathrm{H}$, $\mathrm{CH}=\mathrm{CH}_{2}$-cis), 4.98 (s, $\left.1 \mathrm{H}, \mathrm{H}-1\right), 4.84($ br s, $1 \mathrm{H}, \mathrm{NH}), 4.81$ (dd, $J=5.8$, $3.7 \mathrm{~Hz}, 1 \mathrm{H}, \mathrm{H}-3), 4.58(\mathrm{~d}, J=5.9 \mathrm{~Hz}, 1 \mathrm{H}, \mathrm{H}-2), 4.08$ (dd, $J=13.2$, $\left.5.1 \mathrm{~Hz}, 1 \mathrm{H}, \mathrm{OCHHCH}=\mathrm{CH}_{2}\right), 4.04(\mathrm{ddd}, J=6.2,6.2,3.8 \mathrm{~Hz}, 1 \mathrm{H}, \mathrm{H}-4)$, $3.95\left(\mathrm{dd}, J=13.2,5.8 \mathrm{~Hz}, 1 \mathrm{H}, \mathrm{OCHHCH}=\mathrm{CH}_{2}\right), 3.12-3.20(\mathrm{~m}, 1 \mathrm{H}, \mathrm{H}-$ 5b), 2.99-3.05 (m, $1 \mathrm{H}, \mathrm{H}-5 \mathrm{a}), 1.37$ (s, $\left.3 \mathrm{H}, \mathrm{CCH}_{3}\right), 1.27$ (s, $\left.3 \mathrm{H}, \mathrm{CCH}_{3}\right)$.

${ }^{13} \mathrm{C}$ NMR $\left(150 \mathrm{MHz}\right.$, DMSO- $d_{6}$ ): $\delta=158.0$ (C-pyrimidine), 136.7 (C-pyrimidine), $134.6\left(\mathrm{OCH}_{2} \mathrm{CH}=\mathrm{CH}_{2}\right), 126.7$ ( $\mathrm{CH}$-pyrimidine), 119.4 (C-py-

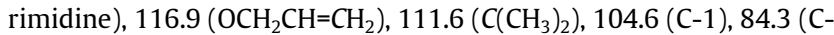
2), $79.3(\mathrm{C}-3), 77.9(\mathrm{C}-4), 67.1\left(\mathrm{OCH}_{2} \mathrm{CH}=\mathrm{CH}_{2}\right), 43.4(\mathrm{C}-5), 26.0\left(\mathrm{CCH}_{3}\right)$, $24.8\left(\mathrm{CCH}_{3}\right)$.

ESI(+)-HRMS: $m / z$ calcd. for $\mathrm{C}_{15} \mathrm{H}_{24} \mathrm{~N}_{5} \mathrm{O}_{4}[\mathrm{M}+\mathrm{H}]^{+}: 338.1828$; found: 338.1822

ESI(+)-HRMS: $m / z$ calcd. for $\mathrm{C}_{15} \mathrm{H}_{21} \mathrm{~N}_{5} \mathrm{NaO}_{4}[\mathrm{M}+\mathrm{Na}]^{+}: 362.1328$; found: 362.1325 .

Benzyl 5-Deoxy-5-(2,4-diaminopyrimidin-5-ylamino)-2,3-0-isopropylidene- $\beta$-L-lyxofuranoside (14d)

Yield: $100 \mathrm{mg}$ (overall yield 26\%); brown-orange amorphous solid.

${ }^{1} \mathrm{H}$ NMR (600 MHz, DMSO- $d_{6}$ ): $\delta=7.23-7.39$ (m, $\left.5 \mathrm{H}, \mathrm{H}-\mathrm{Bn}\right), 7.03(\mathrm{~s}$, $1 \mathrm{H}, \mathrm{CH}$-pyrimidine), 7.00-7.05 (br. s, $2 \mathrm{H}, \mathrm{NH}_{2}$ ), 5.05 (s, $1 \mathrm{H}, \mathrm{H}-1$ ), $4.83(\mathrm{dd}, J=5.8,3.6 \mathrm{~Hz}, 1 \mathrm{H}, \mathrm{H}-3), 4.73(\mathrm{dd}, J=7.2,5.0 \mathrm{~Hz}, 1 \mathrm{H}, \mathrm{NH}$ ), $4.63(\mathrm{~d}, J=6.0 \mathrm{~Hz}, 1 \mathrm{H}, \mathrm{H}-2), 4.61(\mathrm{~d}, J=11.8 \mathrm{~Hz}, 1 \mathrm{H}, \mathrm{CHHPh}), 4.47(\mathrm{~d}$, $J=11.8 \mathrm{~Hz}, 1 \mathrm{H}, \mathrm{CHHPh}), 4.09-4.14(\mathrm{~m}, 1 \mathrm{H}, \mathrm{H}-4), 3.22$ (dd, $J=12.9$, $5.0 \mathrm{~Hz}, 1 \mathrm{H}, \mathrm{H}-5 \mathrm{~b}), 3.08$ (dd, $J=12.9,7.2 \mathrm{~Hz}, 1 \mathrm{H}, \mathrm{H}-5 \mathrm{a}), 1.34(\mathrm{~s}, 3 \mathrm{H}$, $\left.\mathrm{CCH}_{3}\right), 1.23\left(\mathrm{~s}, 3 \mathrm{H}, \mathrm{CCH}_{3}\right)$.

${ }^{13} \mathrm{C}$ NMR (150 MHz, DMSO- $d_{6}$ ): $\delta=159.6$ (C-pyrimidine), 151.6 (C-pyrimidine), 138.0 (C-Bn), 129.0 (C-Bn), 128.6 (C-Bn), 128.4 (C-Bn), 122.1 (CH-pyrimidine), 119.7 (C-pyrimidine), $112.5\left(\mathrm{C}\left(\mathrm{CH}_{3}\right)_{2}\right), 105.2$ (C-1), $84.9(\mathrm{C}-2), 79.8(\mathrm{C}-3), 77.8(\mathrm{C}-4), 68.8\left(\mathrm{OCH}_{2} \mathrm{Ph}\right), 43.0(\mathrm{C}-5), 26.4$ $\left(\mathrm{CCH}_{3}\right), 25.1\left(\mathrm{CCH}_{3}\right)$. 
ESI(+)-HRMS: $m / z$ calcd. for $\mathrm{C}_{19} \mathrm{H}_{25} \mathrm{~N}_{5} \mathrm{O}_{4}[\mathrm{M}+\mathrm{H}]^{+}:$387.1907; found: 387.1911.

ESI(+)-HRMS: $m / z$ calcd. for $\mathrm{C}_{19} \mathrm{H}_{24} \mathrm{~N}_{5} \mathrm{NaO}_{4}[\mathrm{M}+\mathrm{Na}]^{+}: 409.1726$; found: 409.1736 .

\section{General Procedure for the Reduction of the Azides}

$\mathrm{Pd} / \mathrm{C}(5 \% \mathrm{w} / \mathrm{w})$ (100 mg) was added to the corresponding azide (230 $\mathrm{mg}, 1.00 \mathrm{mmol})$ in anhydrous $\mathrm{MeOH}(5 \mathrm{~mL})$ and the reaction mixture was stirred under an atmosphere of hydrogen (1 atm) until completion of the reaction as monitored by TLC (hexanes/EtOAc, 9:1). The reaction mixture was filtered over a pad of Celite ${ }^{\circledR}$ and evaporated to dryness. The product was sufficiently pure to be used without any further purification.

\section{Methyl 5-Amino-5-deoxy-2,3-0-isopropylidene- $\beta$-L-lyxofurano- side (18)}

Yield: $193 \mathrm{mg}$ (95\%); white amorphous solid; $R_{f}\left(\mathrm{CH}_{2} \mathrm{Cl}_{2} / \mathrm{MeOH}\right.$, $95: 5)=0.25$

${ }^{1} \mathrm{H}$ NMR $\left(600 \mathrm{MHz}, \mathrm{CDCl}_{3}\right): \delta=4.89(\mathrm{~s}, 1 \mathrm{H}, \mathrm{H}-1), 4.72(\mathrm{dd}, J=5.8$, $3.9 \mathrm{~Hz}, 1 \mathrm{H}, \mathrm{H}-3$ ), 4.56 (d, J = 5.8 Hz, $1 \mathrm{H}, \mathrm{H}-2), 3.92-3.96$ (m, $1 \mathrm{H}, \mathrm{H}-4)$, 3.32 (s, $3 \mathrm{H}, \mathrm{OCH}_{3}$ ), 2.99-3.09 (m, $\left.2 \mathrm{H}, \mathrm{H}-5 \mathrm{a}, \mathrm{H}-5 \mathrm{~b}\right), 1.45$ (s, $1 \mathrm{H}, \mathrm{CCH}_{3}$ ), $1.30\left(\mathrm{~s}, 1 \mathrm{H}, \mathrm{CCH}_{3}\right)$.

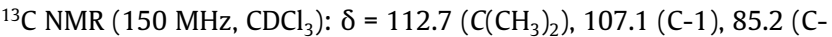
2), 80.7 (C-3), 80.1 (C-4), $54.6\left(\mathrm{OCH}_{3}\right), 40.9(\mathrm{C}-5), 26.1\left(\mathrm{CCH}_{3}\right), 24.8$ $\left(\mathrm{CCH}_{3}\right)$.

${ }^{1} \mathrm{H}$ NMR $\left(600 \mathrm{MHz}\right.$, DMSO- $\left.d_{6}\right): \delta=4.92(\mathrm{~s}, 1 \mathrm{H}, \mathrm{H}-1), 4.79$ (dd, $J=5.9$, $3.8 \mathrm{~Hz}, 1 \mathrm{H}, \mathrm{H}-3), 4.57$ (d, J = 5.9 Hz, $1 \mathrm{H}, \mathrm{H}-2), 4.07-4.13(\mathrm{~m}, 1 \mathrm{H}, \mathrm{H}-4)$, $3.27\left(\mathrm{~s}, 3 \mathrm{H}, \mathrm{OCH}_{3}\right), 3.15$ (dd, $\left.J=13.3,3.3 \mathrm{~Hz}, 1 \mathrm{H}, \mathrm{H}-5^{\prime}\right), 2.92(\mathrm{dd}, J=$ 13.3, $9.0 \mathrm{~Hz}, 1 \mathrm{H}, \mathrm{H}-5), 1.37$ (s, $\left.1 \mathrm{H}, \mathrm{CCH}_{3}\right), 1.26\left(\mathrm{~s}, 1 \mathrm{H}, \mathrm{CCH}_{3}\right)$.

${ }^{13} \mathrm{C}$ NMR (151 MHz, DMSO- $\left.d_{6}\right): \delta=112.0\left(C\left(\mathrm{CH}_{3}\right)_{2}\right), 106.2(\mathrm{C}-1), 85.4$ (C-2), $79.1(\mathrm{C}-3), 75.8(\mathrm{C}-4), 54.1\left(\mathrm{OCH}_{3}\right), 38.0(\mathrm{C}-5), 25.8\left(\mathrm{CCH}_{3}\right), 24.5$ $\left(\mathrm{CCH}_{3}\right)$,

ESI(+)-HRMS: $m / z$ calcd. for $\mathrm{C}_{9} \mathrm{H}_{18} \mathrm{NO}_{4}[\mathrm{M}+\mathrm{H}]^{+}$: 204.1230; found: 204.1221.

\section{Methyl 4-Amino-4-deoxy-2,3-0-isopropylidene- $\beta$-D-ribopyrano- side (20) $)^{4,6,7}$}

Yield: $193 \mathrm{mg}$ (95\%); white amorphous solid; $R_{f}\left(\mathrm{CH}_{2} \mathrm{Cl}_{2} / \mathrm{MeOH}, 95: 5\right)$ $=0.25$.

${ }^{1} \mathrm{H}$ NMR $\left(600 \mathrm{MHz}, \mathrm{CDCl}_{3}\right): \delta=4.37(\mathrm{dd}, J=5.3,3.9 \mathrm{~Hz}, 1 \mathrm{H}, \mathrm{H}-1), 4.34$ (d, $J=4.9 \mathrm{~Hz}, 1 \mathrm{H}, \mathrm{H}-3$ ), 3.94 (dd, $J=13.2,8.0 \mathrm{~Hz}, 1 \mathrm{H}, \mathrm{H}-2$ ), 3.71 (dd, $J=10.8,5.6 \mathrm{~Hz}, 1 \mathrm{H}, \mathrm{H}-5 \mathrm{~b}), 3.46\left(\mathrm{~s}, 3 \mathrm{H}, \mathrm{OCH}_{3}\right), 3.41-3.45(\mathrm{~m}, 1 \mathrm{H}, \mathrm{H}-$ 5a), 3.18-3.24 (m, $1 \mathrm{H}, \mathrm{H}-4), 1.53\left(\mathrm{~s}, 3 \mathrm{H}, \mathrm{CCH}_{3}\right), 1.37\left(\mathrm{~s}, 3 \mathrm{H}, \mathrm{CCH}_{3}\right)$.

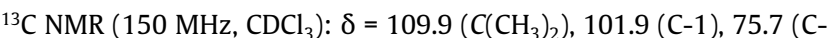
2), 74.5 (C-3), 65.1 (C-5), $56.4\left(\mathrm{OCH}_{3}\right), 49.9(\mathrm{C}-4), 27.5\left(\mathrm{CCH}_{3}\right), 25.6$ $\left(\mathrm{CCH}_{3}\right)$.

ESI(+)-HRMS: $m / z$ calcd. for $\mathrm{C}_{9} \mathrm{H}_{18} \mathrm{NO}_{4}[\mathrm{M}+\mathrm{H}]^{+}$: 204.1230; found: 204.1224 .

Data in agreement with the literature.,4,6,7

\section{2,3-0-Isopropylidene-L-lyxofuranose (19)}

A suspension of the benzyl protected compound $3(140 \mathrm{mg}, 0.5 \mathrm{mmol}$, 1.0 equiv) with $\mathrm{Pd}(\mathrm{OH})_{2}$ in anhydrous $\mathrm{MeOH}$ was stirred at r.t. under an atmosphere of hydrogen for 1 day. The suspension was filtered through a pad of Celite ${ }^{\circledR}$ and washed several times with $\mathrm{MeOH}$. The solvent was removed under reduced pressure and the crude product was purified by column chromatography (hexanes/EtOAc, 3:7) to afford the expected product 19.
Yield: $650 \mathrm{mg}$ (98\%); $R_{f}$ (hexanes/EtOAc, 7:3) $=0.50$.

${ }^{1} \mathrm{H}$ NMR $\left(600 \mathrm{MHz}\right.$, DMSO- $\left.d_{6}\right): \delta=6.31\left(\mathrm{~d}, J=3.8 \mathrm{~Hz}, 1 \mathrm{H}, \mathrm{C}^{1} \mathrm{OH}\right), 5.10$ (d, J= 3.8 Hz, $1 \mathrm{H}, \mathrm{H}-1), 4.65-4.72(\mathrm{~m}, 2 \mathrm{H}, \mathrm{OH}, \mathrm{H}-3), 4.42$ (d, J= 5.8 Hz, $1 \mathrm{H}, \mathrm{H}-2$ ), 3.97-4.03 (m, $1 \mathrm{H}, \mathrm{H}-4), 3.62$ (dt, $J=11.2,5.5 \mathrm{~Hz}, 1 \mathrm{H}, \mathrm{H}-5 \mathrm{~b}$ ), 3.46-3.53 (m, $1 \mathrm{H}, \mathrm{H}-5 \mathrm{a}), 1.32\left(\mathrm{~s}, 3 \mathrm{H}, \mathrm{CCH}_{3}\right), 1.22\left(\mathrm{~s}, 3 \mathrm{H}, \mathrm{CCH}_{3}\right)$.

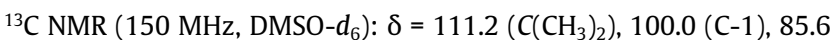
(C-2), 80.0 (C-4), 79.5 (C-3), 59.2 (C-5), $26.0\left(\mathrm{CCH}_{3}\right), 24.7\left(\mathrm{CCH}_{3}\right)$.

ESI(+)-HRMS: $m / z$ calcd for $\mathrm{C}_{8} \mathrm{H}_{15} \mathrm{O}_{5}[\mathrm{M}+\mathrm{H}]^{+}$: 191.0914; found: 191.0909 .

\section{Methyl 4-Deoxy-4-formamido-2,3-0-isopropylidene- $\beta$-D-ribopy- ranoside (21)}

A solution of 5-bromouracil (573 $\mathrm{mg}, 3.00 \mathrm{mmol}$ ) and 4-deoxy-4amino-2,3-O-isopropylidene- $\beta$-D-ribopyranoside 20 (203 mg, 1.00 $\mathrm{mmol})$ in anhydrous dimethylformamide $(5 \mathrm{~mL})$ was stirred at $70{ }^{\circ} \mathrm{C}$ overnight. The mixture was allowed to cool, then saturated aqueous $\mathrm{NaHCO}_{3}$ was added. The aqueous phase was extracted three times with EtOAc and the organic layers were combined, dried with $\mathrm{Na}_{2} \mathrm{SO}_{4}$, filtered and evaporated. The oily residue was purified by column chromatography (hexanes/EtOAc, 7:3) to afford the expected pure product 21.

Yield: $231 \mathrm{mg}$ (56\%); white amorphous solid; $R_{f}$ (hexane/EtOAc, 7:3) = 0.5 .

${ }^{1} \mathrm{H}$ NMR $\left(600 \mathrm{MHz}, \mathrm{CDCl}_{3}\right): \delta=8.16(\mathrm{~s}, 1 \mathrm{H}, \mathrm{COH}), 6.01(\mathrm{~d}, J=7.7 \mathrm{~Hz}$, $1 \mathrm{H}, \mathrm{NH}), 4.58-4.64(\mathrm{~m}, 1 \mathrm{H}, \mathrm{H}-4), 4.42$ (d, $J=4.2 \mathrm{~Hz}, 1 \mathrm{H}, \mathrm{H}-1), 4.35$ (dd, $J=6.0,4.2 \mathrm{~Hz}, 1 \mathrm{H}, \mathrm{H}-3$ ), 4.03 (dd, $J=6.0,4.4 \mathrm{~Hz}, 1 \mathrm{H}, \mathrm{H}-2$ ), 3.82 (dd, $J=10.6,5.7 \mathrm{~Hz}, 1 \mathrm{H}, \mathrm{H}-5 \mathrm{~b}), 3.43\left(\mathrm{~s}, 3 \mathrm{H}, \mathrm{OCH}_{3}\right), 3.42-3.45(\mathrm{~m}, 1 \mathrm{H}$, $\mathrm{H}-5 \mathrm{a}), 1.49$ (s, $\left.3 \mathrm{H}, \mathrm{CCH}_{3}\right), 1.32\left(\mathrm{~s}, 3 \mathrm{H}, \mathrm{CCH}_{3}\right)$.

${ }^{13} \mathrm{C} \mathrm{NMR}\left(150 \mathrm{MHz}, \mathrm{CDCl}_{3}\right): \delta=160.8(\mathrm{CHO}), 110.1\left(\mathrm{C}\left(\mathrm{CH}_{3}\right)_{2}\right), 100.1(\mathrm{C}-$ 1), 75.1 (C-2), 72.5 (C-3), $61.0(\mathrm{C}-5), 56.3\left(\mathrm{OCH}_{3}\right), 43.0(\mathrm{C}-4), 27.1$ $\left(\mathrm{CCH}_{3}\right), 25.4\left(\mathrm{CCH}_{3}\right)$.

ESI(+)-HRMS: $m / z$ calcd. for $\mathrm{C}_{10} \mathrm{H}_{18} \mathrm{NO}_{5}[\mathrm{M}+\mathrm{H}]^{+}:$232.1179; found: 232.1181.

ESI(+)-HRMS: $m / z$ calcd. for $\mathrm{C}_{10} \mathrm{H}_{17} \mathrm{NNaO}_{5}[\mathrm{M}+\mathrm{Na}]^{+}: 254.0999$; found: 254.1003.

\section{Methyl 4-Benzoylamino-4-deoxy-2,3-0-isopropylidene- $\alpha$-D-ri- bopyranoside (22)}

To a solution of methyl 4-deoxy-4-amino-2,3-0-isopropylidene- $\beta$-Dribopyranoside 20 (190 mg, $0.80 \mathrm{mmol}, 1.0$ equiv) and DIPEA ( 0.31 $\mathrm{mL}, 1.76 \mathrm{mmol}, 2.2$ equiv) in anhydrous dimethylformamide $(5 \mathrm{~mL})$, benzoyl chloride $(0.21 \mathrm{~mL}, 1.82 \mathrm{mmol}, 2.0$ equiv) was slowly added at $0{ }^{\circ} \mathrm{C}$ under an argon atmosphere. The solution was stirred at $70{ }^{\circ} \mathrm{C}$ overnight. The mixture was allowed to cool, then saturated aqueous $\mathrm{NaHCO}_{3}$ was added. The aqueous phase was extracted three times with EtOAc and the organic layers were combined, dried with $\mathrm{Na}_{2} \mathrm{SO}_{4}$, filtered and evaporated. The oily residue was purified by chromatography (hexanes/EtOAc, 7:3) to afford the expected pure product 22.

Yield: $201 \mathrm{mg}$ (82\%); white amorphous solid; $R_{f}$ (hexanes/EtOAc, $9: 1)=0.50$.

${ }^{1} \mathrm{H}$ NMR $\left(600 \mathrm{MHz}, \mathrm{CDCl}_{3}\right): \delta=7.79$ (d, $\left.J=7.2 \mathrm{~Hz}, 2 \mathrm{H}, \mathrm{H}-\mathrm{Bz}\right), 7.51$ (dd, $J=7.4,7.2 \mathrm{~Hz}, 1 \mathrm{H}, \mathrm{H}-\mathrm{Bz}), 7.44(\mathrm{dd}, J=7.4,7.4 \mathrm{~Hz}, 2 \mathrm{H}, H-\mathrm{Bz}), 6.48$ (d, $J=8.8 \mathrm{~Hz}, 1 \mathrm{H}, \mathrm{NHCO}), 4.74-4.80(\mathrm{~m}, 1 \mathrm{H}, \mathrm{H}-4), 4.45-4.49(\mathrm{~m}, 2 \mathrm{H}, \mathrm{H}-$ 3, $\mathrm{H}-1$ ), 4.09 (dd, $J=6.1,4.5 \mathrm{~Hz}, 1 \mathrm{H}, \mathrm{H}-2), 3.97$ (dd, $J=10.6,6.5 \mathrm{~Hz}$, $1 \mathrm{H}, \mathrm{H}-5 \mathrm{~b}), 3.49-3.54(\mathrm{~m}, 1 \mathrm{H}, \mathrm{H}-5 \mathrm{a}), 3.49$ (s, $\left.3 \mathrm{H}, \mathrm{OCH}_{3}\right), 1.54(\mathrm{~s}, 3 \mathrm{H}$, $\left.\mathrm{CCH}_{3}\right), 1.38\left(\mathrm{~s}, 3 \mathrm{H}, \mathrm{CCH}_{3}\right)$.

${ }^{13} \mathrm{C}$ NMR $\left(150 \mathrm{MHz}, \mathrm{CDCl}_{3}\right): \delta=167.7(\mathrm{CO}), 131.8(\mathrm{C}-\mathrm{Bz}), 128.6(\mathrm{C}-\mathrm{Bz})$,

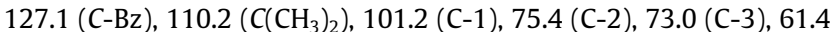
(C-5), $59.4\left(\mathrm{OCH}_{3}\right), 44.8(\mathrm{C}-4), 27.3\left(\mathrm{CCH}_{3}\right), 25.6\left(\mathrm{CCH}_{3}\right)$. 
ESI(+)-HRMS: $m / z$ calcd. for $\mathrm{C}_{16} \mathrm{H}_{22} \mathrm{NO}_{5}[\mathrm{M}+\mathrm{H}]^{+}$: 308.1492 ; found: 308.1492 .

\section{Funding Information}

This work was supported jointly by the NSF Center for Chemical Evolution, Grant CHE-1504217.

\section{Acknowledgment}

We are grateful to Mr. Richard Mosesso for the purification of some starting materials and Dr. Clémentine Gibard for the assistance in running selected NMR spectra.

\section{Supporting Information}

Supporting information for this article is available online at https://doi.org/10.1055/s-0036-1588859. It contains ${ }^{1} \mathrm{H}, \mathrm{APT}\left(\right.$ or ${ }^{13} \mathrm{C}$ ) and 2D (HSQC and/or COSY) NMR spectral data of all compounds in $\mathrm{CDCl}_{3}$ and/or DMSO- $d_{6}$. It also contains HMBC of the compounds $\mathbf{1 , 5}$ and 12c, NOESY NMR spectra of compounds $2,3,5,6,12 c, 15 a$ and 18, a figure comparing APT NMR of lyxofuranoside 1-3 and lyxopyranosides 5-7, a figure comparing ${ }^{1} \mathrm{H}$ NMR among the compounds $\mathbf{1}$ and $\mathbf{5}$, and crude material of $\mathbf{5}$, and experimental procedures for the synthesis of starting materials 1-7 and compound 19.

\section{References}

(1) Mittapalli, G. K.; Ravinder, K. R.; Xiong, H.; Munoz, O.; De Riccardis, F.; Krishnamurthy, R.; Eschenmoser, A. Angew. Chem. Int. Ed. 2007, 46, 2470.

(2) Mittapalli, G. K.; Osornio, Y. M.; Guerrero, M. A.; Ravinder, K. R.; Krishnamurthy, R.; Eschenmoser, A. Angew. Chem. Int. Ed. 2007, 46, 2478.

(3) Zhang, X.; Krishnamurthy, R. Angew. Chem. Int. Ed. 2009, 48, 8124.
(4) Kini, G. D.; Hennen, W. J. J. Org. Chem. 1986, 51, 4436.

(5) Kini, G. D.; Petrie, C. R.; Hennen, W. J.; Dalley, N. K.; Wilson, B. E.; Robins, R. K. Carbohydr. Res. 1987, 159, 81.

(6) Varaprasad, C. V.; Averett, D.; Ramasamy, K. S. Tetrahedron 1999, 55, 13345.

(7) Varaprasad, C. V.; Ramasamy, K. S.; Hong, Z. J. Heterocycl. Chem. 2006, 43, 325

(8) Wakharkar, R. D.; Sahasrabuddhe, M. B.; Borate, H. B.; Gurjar, M. K. Synthesis 2004, 1830.

(9) Keck, G. E.; Kachensky, D. F.; Enholm, E. J. J. Org. Chem. 1985, 50, 4317.

(10) Mohal, N.; Vasella, A. Helv. Chim. Acta 2005, 88, 100.

(11) Mohal, N.; Bernet, B.; Vasella, A. Helv. Chim. Acta 2005, 88, 3232.

(12) Keck, G. E.; Wager, T. T.; Duarte Rodriquez, J. F. J. Am. Chem. Soc. 1999, 121, 5176.

(13) Reist, E. J.; Fisher, L. V.; Goodman, L. J. Org. Chem. 1967, 32, 2541.

(14) Ozerov, A. A.; Novikov, M. S.; Brel', A. K.; Solodunova, G. N. Chem. Heterocycl. Compd. 1998, 34, 611.

(15) Loksha, Y. M.; Globisch, D.; Pedersen, E. B. J. Heterocycl. Chem. 2008, 45, 1161.

(16) Boncel, S.; Gondela, A.; Mączka, M.; Tuszkiewicz-Kuźnik, M.; Grec, P.; Hefczyc, B.; Walczak, K. Synthesis 2011, 603.

(17) Gems, F. R.; Perrotta, A.; Hitching, G. H. J. Med. Chem. 1966, 9, 108.

(18) Sørensen, M. D.; Khalifa, N. M.; Pedersen, E. B. Synthesis 1999, 1937.

(19) Fang, W.-P.; Cheng, Y.-T.; Cheng, Y.-R.; Cherng, Y.-J. Tetrahedron 2005, 61, 3107.

(20) Suchý, M.; Elmehriki, A. A. H.; Hudson, R. H. E. Org. Lett. 2011, $13,3952$.

(21) Coleman, R. S.; Felpin, F.-X.; Chen, W. J. Org. Chem. 2004, 69, 7309.

(22) Kawana, M.; Kuzuhara, H.; Emoto, S. Bull. Chem. Soc. Jpn. 1981, $54,1492$.

(23) Brimacombe, J. S.; Hunedy, F.; Tucker, L. C. N. J. Chem. Soc. C 1968, 1381.

(24) Jogireddy, R.; Dakas, P.-Y.; Valot, G.; Barluenga, S.; Winssinger, N. Chem. Eur. J. 2009, 15, 11498. 